\title{
EL RECONOCIMIENTO DE DERECHOS SUCESORIOS A LAS PAREJAS DE HECHO EN ESPAÑ*
}

\author{
Susana Espada Mallorquín
}

RESUMEN

En España, en los últimos años estamos asistiendo a un cambio vertiginoso y esencial del Derecho de Familia y de Sucesiones. A pesar de estas reformas, el reconocimiento de efectos jurídicos, especialmente, de derechos sucesorios a las parejas de hecho, sigue siendo una asignatura pendiente. El presente artículo realiza una breve referencia al marco jurídico y al concepto de la pareja de hecho desde una perspectiva legislativa y jurisprudencial. El núcleo esencial del estudio es el análisis de las soluciones que los tribunales adoptan ante la solicitud del reconocimiento de efectos jurídicos sucesorios por las convivencias more uxorio y la propuesta del reconocimiento de determinados efectos jurídicos mortis causa del cónyuge viudo al conviviente supérstite mediante el empleo del argumento jurídico por analogía.

Palabras claves: parejas de hecho, sucesiones, cónyuge viudo, analogía.

AbSTRACT

In recent years, Spain has achieved an essential and dizzy evolution in Family and Succession Law. In spite of these reforms, the recognition of legal effects, especially, the succession rights of the unmarried couple, it's still being an unresolved matter. The present article carry out a brief reference to the judicial framework and the concept of unmarried couple from the statutes and the case law perspective. The study essence is the breakdown

* El presente artículo tiene como objetivo destacar algunas de las principales conclusiones del desarrollo de mi tesis doctoral sobre esta misma materia, que se encuentra publicada como monografía con el título Los derechos sucesorios de la pareja de hecho, Navarra, ThomsonCivitas, 2007. En ella el lector interesado podrá encontrar un desarrollo más exhaustivo de los temas propuestos.

** Profesora de Derecho Civil en la Universidad Carlos III de Madrid. Correo electrónico: susana.espada@uam.es y sespada@der-pr.uc3m.es. Artículo recibido el 5 de marzo de 2009 y aceptado el 6 de abril de 2009. 
of the solutions that Courts have adopt when the unmarried couple requests for the recognition of succession rights and the author propounds the recognition to unmarried couples of certain succession rights that are legally recognised to the widowed spouse by means of analogy.

Key words: unmarried couple, succession, widowed spouse, analogy.

\section{INTRODUCCIÓN}

En España, durante los últimos diez años, estamos asistiendo a un cambio vertiginoso y esencial del Derecho de Familia y de Sucesiones. Estos cambios son especialmente complejos por las peculiaridades relativas al reparto de competencias legislativas que rige en el ordenamiento jurídico español entre el Estado y las comunidades autónomas ${ }^{1}$. No obstante, el presente estudio se limitará a analizar la situación en el Derecho Civil común.

En el plano del Derecho de Familia, es necesario partir de la importante evolución producida en la imagen de la institución familiar. Así, cabe destacar el cambio de los valores tradicionales; el predominio de la autonomía de la voluntad individual y los avances en la supresión de la discriminación 10 por razón de sexo -validez del matrimonio contraído entre personas del mismo sexo- ${ }^{2}$. Estos cambios también han afectado de manera esencial a la imagen del matrimonio, sustituyéndose su idea como vínculo legal y destino para toda la vida, por la concepción como proyecto de vida en común, cuyas consecuencias se producen mientras subsista la convivencia. La mayor libertad y la voluntariedad del desarrollo de las relaciones afectivas traen consigo la mayor vulnerabilidad de los vínculos que se crean en el desarrollo de la convivencia matrimonial. Esto subyace, por un lado, respecto del matrimonio, en la reforma realizada por la Ley 15/2005, de

${ }^{1}$ En el artículo 143 de la CE de 1978 se reconoce a las provincias con características históricas, culturales y económicas comunes, a los territorios insulares y a las provincias con entidad regional histórica, la posibilidad de acceder al autogobierno y constituirse en comunidades autónomas. Tras esta asunción de competencias por las diferentes comunidades autónomas en sus respectivos estatutos de autonomía, en el ordenamiento jurídico español es necesario estudiar no sólo las normas estatales sino, también, las normas autonómicas. En concreto, en materia de las parejas de hecho, a fines de los años noventa sólo se las mencionaba someramente en algunas normas estatales y sólo dos comunidades autónomas, de las diecisiete existentes en España, contaban con una ley específica de parejas de hecho. Hoy, el legislador estatal prosigue reconociendo en forma parcial efectos jurídicos a estas relaciones, pero de las citadas comunidades autónomas, tan sólo cuatro carecen de una regulación en esta materia.

${ }^{2}$ Ley 13/2005, de 1 de julio, que modifica el Código Civil en materia de derecho a contraer matrimonio. 
8 de julio, por la que desaparece la necesidad de tener que alegar alguna causa legal para que proceda la separación o el divorcio y, por otro, en la creciente aceptación social de la pareja de hecho como una fórmula válida para desarrollar una comunidad de vida y afectos.

Por su parte, dentro de la evolución del Derecho de Sucesiones, es especialmente destacable el reconocimiento cada vez más amplio de la libertad de testar de los individuos ${ }^{3}$; el reforzamiento de la posición hereditaria del cónyuge supérstite -en consonancia con la nueva concepción de la familia como comunidad de vida y no como comunidad de parentesco-; la equiparación de todos los hijos, con independencia de la filiación, y la protección de los más débiles (discapacitados) ${ }^{4}$; la reducción de los parientes considerados legitimarios y la progresiva eliminación en la sucesión intestada del llamamiento a los colaterales más remotos. De hecho, anticipando una idea que se desarrollará posteriormente, creo que estas tendencias son las que motivan las recientes reformas del Código Civil, donde la voluntad de los cónyuges y la efectiva convivencia more uxorio (al modo matrimonial) son los elementos relevantes para reconocerles derechos sucesorios, más que la propia vigencia del vínculo matrimonial (v.gr., pérdida de los derechos legitimarios en los supuestos de separación de hecho $)^{5}$.

${ }^{3}$ La Ley 7/2003, de 1 de abril, de la Sociedad Limitada Nueva Empresa reforma el contenido de los artículos 1056 y 1271 del CC. El objetivo de esta modificación consiste en adaptar la normativa mercantil española a diversas Directivas comunitarias y en adecuar la sucesión de la empresa a estas nuevas circunstancias. Para ello, se admite que, mediante disposición testamentaria, el causante establezca el pago en metálico de la legítima a los herederos forzosos, para poder garantizar con ello el futuro control de la empresa familiar de una sociedad de capital o de un grupo de las mismas. A su vez, se excepciona la regla de la herencia futura y se permite la celebración de contratos que tengan por objetivo realizar inter vivos la división del caudal y otras operaciones particionales conforme con las nuevas disposiciones del artículo $1056 \mathrm{del} C C$.

${ }^{4}$ Destacan las reformas de la Ley 41/2003, de 18 de noviembre, de protección patrimonial de las personas con discapacidad y de modificación del Código Civil, de la Ley de Enjuiciamiento Civil y de la Normativa Tributaria. Se busca la mejora de la protección patrimonial de las personas con discapacidad y para ello, en el ámbito sucesorio, se modifican las causas de indignidad, se admite el gravamen de la legítima estricta mediante una sustitución fideicomisaria -aunque sólo cuando esto beneficie a un hijo o un descendiente judicialmente incapacitado-, se crean medidas de protección patrimonial directa (reforma el art. 822 CC) e indirecta (reforma del art. 831 del $C C$ ) y se introduce un nuevo párrafo al artículo 1041 del $C C$ con el fin de evitar la colación de los gastos realizados por los padres o ascendientes -entendiendo por estos gastos cualquier disposición patrimonial-, para cubrir las necesidades especiales de sus hijos o descendientes con discapacidad.

${ }^{5}$ Por la Ley 13/2005, de 1 de julio por la que se modifica el Código Civil en materia de derecho a contraer matrimonio, le corresponderán idénticos derechos sucesorios a los matrimonios entre personas de distinto o del mismo sexo. Por su parte, la Ley 15/2005, de 8 de julio, que modifica el Código Civil en materia de separación y divorcio, tiene como principal objetivo reforzar el principio de libertad de los cónyuges en el matrimonio, lo que en 
Sin embargo, a pesar de los mencionados avatares legislativos, la pareja de hecho sigue siendo una asignatura pendiente para el legislador estatal español. El tema central del presente artículo es el planteamiento de los problemas jurídicos que suscita el fallecimiento de uno de los convivientes de la pareja de hecho y la aportación de las posibles soluciones que, dentro del ordenamiento vigente, pueden arbitrarse a tal efecto. Para ello, entiendo que es preciso realizar una reflexión previa relativa a la determinación de cuáles son los fundamentos que justifican el reconocimiento de efectos jurídicos a las parejas de hecho y su reconocimiento estatal actual, así como qué características ha de reunir la pareja de hecho a la que, en su caso, procederemos a reconocerle efectos jurídico en el ámbito sucesorio.

\section{LOS FUNDAMENTOS DEL RECONOCIMIENTO}

DE EFECTOS JURÍDICOS A LAS PAREJAS DE HECHO

Es evidente que las personas han convivido en todas las civilizaciones, pero a lo largo de la historia han sido muy diversas las opciones legislativas que se han adoptado sobre su desarrollo de forma institucionalizada o no ${ }^{6}$. La pareja de hecho como forma de organización de la vida en común no es un fenómeno históricamente nuevo, por lo que se puede afirmar que, en la actualidad en España, no nos encontramos ante una expansión de este tipo de convivencia, sino, más bien, ante su aceptación social como fórmula válida para el inicio de un proyecto de vida en común y, por ende, susceptible de reconocimiento de efectos jurídicos ${ }^{7}$.

Para enfocar de forma genérica el fundamento de este reconocimiento a las parejas de hecho, se puede partir tanto de una perspectiva sociológica,

materia sucesoria, implica que se modifiquen ciertas disposiciones relativas al reconocimiento de derechos sucesorios al cónyuge viudo, en concreto, se establece una nueva redacción para los artículos 834, 835, 837, 840 y 945 del $C C$. Tras esta reforma, la mera separación de hecho, al igual que la separación judicial, motiva la pérdida de la legítima consistente en el usufructo viudal, desapareciendo, a su vez, cualquier referencia a la culpa del premuerto en esta separación. Se eliminan los requisitos que la separación de hecho debía reunir para que no procediera el llamamiento ab intestato del cónyuge supérstite separado de hecho y se suprime tanto la posibilidad de continuar el pleito de separación tras el fallecimiento de uno de los consortes como la ampliación de la cuota legitimaria del cónyuge supérstite a un medio, cuando concurre con hijos extramatrimoniales del premuerto.

${ }^{6}$ Para una perspectiva sociológica, véase, entre otros, Friedrich ENGELS, El origen de la familia, Madrid, Albor, 1998; Claude Levi-Strauss, Las estructuras elementales del parentesco, Barcelona, Paidós, 1969 y Andrée Michel, Sociología de la familia y del matrimonio, Barcelona, Península, N $^{\circ}$ 109, 1974.

${ }^{7}$ Gerardo Meil Landwerlin, Las uniones de hecho en España, Madrid, Centro de Investigaciones Sociológicas, Monografía No 201, 2003, p. 247. 
dado que el aumento del porcentaje de parejas que conviven de hecho es una realidad social notoria de los últimos años ${ }^{8}$, como de una perspectiva jurídica, puesto que progresivamente dicho reconocimiento de efectos se lleva a cabo por parte del legislador estatal y de la jurisprudencia.

\section{La realidad sociológica de las parejas de hecho en España}

Del punto de vista sociológico se considera que el incremento de este tipo de parejas está íntimamente relacionado con la crisis de la institución matrimonial ${ }^{9}$. Dentro del contexto social y temporal español, esta crisis viene determinada por la proliferación de las rupturas conyugales y por el menor número de celebraciones matrimoniales. La combinación de estos datos permite concluir que en la sociedad española hay un menor grado de apoyo social a esta institución como compromiso solemne que trae consigo un reconocimiento social ${ }^{10}$. Otros indicadores de esta crisis son la progresiva relajación de la causalidad del divorcio -hasta su definitiva eliminación por la Ley 15/2005, de 8 de julio-, el debilitamiento del criterio de culpabilidad y la inutilidad, en la práctica, de la separación legal como remedio para rehacer la convivencia conyugal. De hecho, recientes estudios sociológicos han demostrado que la convivencia en pareja de hecho es la opción de proyecto de vida más generalizada, siempre que uno de los miembros de la pareja haya pasado por una convivencia matrimonial previa que ha resultado insatisfactoria ${ }^{11}$.

Otro detonante de la crisis de la institución matrimonial, es el progresivo laicismo social. Es innegable la influencia que en el Derecho de Familia de los países occidentales tuvo la sacralización de las instituciones familiares y el conjunto de creencias y comportamientos religiosos de la sociedad. En el caso español, la aconfesionalidad del Estado y la libertad religiosa ponen

${ }^{8}$ En España se ha producido un incremento de la aceptación de las parejas de hecho como una forma válida de establecimiento de un proyecto de vida común en pareja (véase Barómetro de junio del CIS, estudio 2568, junio de 2004), al igual que un progresivo aumento del número de parejas que conviven more uxorio (véase ese mismo estudio y los posteriores Barómetros de diciembre de 2005 (Estudio 2630) y de junio de 2006 (Estudio 2649) del CIS; www.cis.es, última visita enero 2007).

${ }^{9}$ Víctor Reina y José María Martinell, Las uniones matrimoniales de hecho, Madrid, Marcial Pons, 1996, pp. 9-11.

${ }^{10}$ Inés Alberdi, La nueva familia española, Madrid, Taurus, 1999, p. 127.

${ }^{11}$ Según este estudio, al menos tres de cada cuatro personas que conviven por segunda vez han iniciado su segundo proyecto de vida en común mediante un vínculo de hecho. Véase Meil Landwerlin (n. 7), p. 247 y "Actitudes y uso social de las uniones de hecho en España", Anuario de la Facultad de Derecho de la Universidad Autónoma de Madrid, № 10 , Madrid, 2006, p. 95 y ss. 
en cuestión esos fundamentos sacrales del orden familiar, agudizándose con ello la crisis de la institución; es decir, la pérdida de la relevancia de este elemento moral o religioso provoca un mayor protagonismo de la autonomía de la voluntad del individuo ${ }^{12}$.

A su vez, nos enfrentamos a un cambio sociológico y jurídico del concepto de matrimonio. El significado y el sentido del matrimonio actual se encuentran en su dimensión instrumental y, de ser así, entiendo que no existe un impedimento para institucionalizar jurídicamente otros modelos afectivos alternativos al matrimonial ${ }^{13}$. De hecho, existe una gran variedad de modalidades de cohabitación. Desde un punto de vista sociológico, predominan las convivencias more uxorio que se caracterizan, entre otros elementos, por tener un menor número de hijos que las relaciones matrimoniales y porque en la organización interna del trabajo doméstico, el reparto de las tareas entre los géneros es más igualitario que en el matrimonio. No obstante, la calidad de las relaciones es similar a la matrimonial, existiendo en ambos casos -matrimonio y pareja de hecho- desavenencias y maltrato. También es posible afirmar que, cuando no existe un proyecto de vida familiar inmediato y las inversiones en el proyecto de vida común no son muy elevadas, se tiende a emplear la convivencia de hecho como un matrimonio a prueba. Respecto a la organización de la convivencia por 14 parte de las parejas del mismo sexo se caracterizan por una mayor independencia económica entre sus miembros $\mathrm{y}$, a diferencia de un pasado no muy lejano, actualmente las familias de origen no condenan a los miembros de estas parejas de hecho ${ }^{14}$.

\section{El marco jurídico actual de las parejas de hecho}

Para poder determinar su marco jurídico actual en el ordenamiento español, creo oportuno distinguir su situación desde una doble perspectiva: constitucional y legislativa, y dentro de esta última es preciso diferenciar entre la regulación estatal y autonómica, si bien como ya he mencionado, en el presente artículo no me voy a detener en el análisis de esta última.

${ }^{12}$ Jean Carbonnier, Derecho flexible. Para una sociología no rigurosa del Derecho, Madrid, Tecnos, 1974, pp. 169-175 y Flexible Droit. Pour une sociologie du Droit sans rigueur, 10a ed., Paris, L.G.D.J., 2001, p. 265.

${ }^{13}$ En este sentido, véase también Pedro A. Talavera Fernández, La unión de hecho y el derecho a no casarse, Granada, Comares, 2001, p. 21.

${ }^{14}$ Meil Landwerlin (n. 7), pp. 249-252. 


\section{a) Perspectiva constitucional}

Es evidente que en la CE de 1978 no existe ningún precepto expreso que contemple a las parejas de hecho y que sirva para fundamentar el reconocimiento de efectos jurídicos a las mismas directamente desde una perspectiva constitucional.

Ahora bien, sí existen diversos artículos que pueden servir de base para legitimar su reconocimiento jurídico. Estos preceptos constitucionales son el artículo 32 de la $\mathrm{CE}$, donde se contempla el derecho a contraer matrimonio; el artículo 39 de la CE, que garantiza la protección de la institución familiar, los hijos y la madre y, el artículo 10.1 de la $\mathrm{CE}$, relativo al libre desarrollo de la personalidad y que fundamenta la libertad individual y el mandato constitucional de respeto al derecho de todo individuo a vivir y comportarse de acuerdo con sus propias convicciones y a decidir la forma en la que desarrolla sus relaciones de afectividad (siempre y cuando con ello no se dañe de forma injusta a los demás). No obstante, hay que señalar que la doctrina y la jurisprudencia del Tribunal Constitucional resultan contradictorias a la hora de reconocer efectos jurídicos a la convivencia more uxorio. El problema se centra, principalmente, en la dificultad de encontrar el equilibrio necesario entre la protección constitucional del matrimonio, la garantía institucional de la familia y el respeto a la libertad individual y el libre desarrollo de la personalidad.

A grandes rasgos, respecto a la protección constitucional de la familia contemplada en el artículo 39 de la CE, ésta se deriva de su consideración como institución que ha de ser garantizada. La garantía institucional de la familia implica el respeto de sus rasgos esenciales (imagen maestra: Leit Bild $)^{15}$; rasgos que no determinan un contenido concreto, estático y determinado de familia. Por lo tanto, para poder afirmar que la pareja de hecho está incluida en la garantía institucional de la familia protegida por la Constitución, es necesario precisar su imagen maestra, es decir, los rasgos básicos de esta institución familiar en la actualidad ${ }^{16}$.

${ }^{15}$ Sobre el concepto de garantía institucional véase, entre otros, Pedro CRUz Villalón, "Formación y evolución de los Derechos fundamentales", en Revista Española de Derecho Constitucional, año 9, $\mathrm{N}^{\circ}$ 25, Madrid, enero-abril 1989, pp. 35-62; Luciano PAREJo Alfonso, Garantía institucional y Administraciones locales, Madrid, Instituto de Estudios de la Administración Local, 1981, Antonio Jiménez Blanco, "Garantías institucionales y derechos fundamentales en la Constitución”, en Sebastián Martín-Retortillo Baquer (coord.), Estudios sobre la Constitución española: Homenaje al profesor Eduardo García de Enterría, Navarra, Civitas, 1991, vol. 2, pp. 635-650 y Juan J. SOlOzÁBAl ECHAVARRIA, "Garantías institucionales", en Aragón, Manuel (coord.), Temas básicos de Derecho Constitucional, Madrid, Civitas, 2001, tomo III: Tribunal constitucional y derechos fundamentales, pp. 110-113.

${ }^{16}$ Luis Flaquer, “¿Hogares sin familia o familias sin hogar?”, en Papers: Revista de Sociología, No 36, erevistas.csic.es, 1991, pp. 68-69 y El destino de la familia, Barcelona, Ariel, 
En España, el estudio de la evolución de las relaciones familiares revela que durante mucho tiempo se presentaba a la familia como una convivencia basada en el matrimonio, indisoluble, heterosexual y con una finalidad esencialmente reproductora ${ }^{17}$. En la actualidad, esta imagen familiar ha cambiado, entre otros motivos, por la modificación de la manera de concebir las relaciones sexuales, por el mencionado cambio de los valores tradicionales y el predominio de la autonomía de la voluntad individual, por la salida de la homosexualidad de lo patológico, por la incorporación de la mujer al mundo laboral y por la pérdida de influencia de la moral católica en la vida social ${ }^{18}$. Éstos son algunos de los elementos de los que se deriva el cambio esencial en la percepción de las diversas formas de convivencia y la disociación entre matrimonio, sexualidad y procreación. En este proceso evolutivo también influye el cambio ideológico que implica la aprobación de la ley del divorcio, la equiparación de la filiación extramatrimonial y matrimonial y la protección estatal de la maternidad y de la infancia. Así, la función esencial del grupo familiar sigue presente, pero es posible constatar un cambio a la hora de determinar cuáles son los modelos de familia y sus procesos de formación ${ }^{19}$. Además, se aprecia un cambio de las funciones socioeconómicas de la familia y una progresiva asunción de sus funciones de protección por parte del Estado ${ }^{20}$.

16 A su vez, hay que tener presente que el matrimonio y la familia son dos instituciones relacionadas estrechamente, aunque no correspondan a la misma realidad. En el debate constitucional español, la necesidad de

1998, pp. 87-91 y Rosario VALPUESTA FERnÁNdez, "Otras miradas sobre la familia. La familia y sus funciones”, en José Manuel GonzÁlez Porras y Fernando P. Méndez González (coords.) Libro homenaje al profesor Manuel Albaladejo García, Murcia, Secretariado de Publicaciones e Intercambio Científico de la Universidad de Murcia, 2004, vol. 2, pp. 4.915-4.932.

${ }^{17}$ Véase Alberdi (n. 10); Salustiano del Campo Urbano, La nueva familia española, Madrid, Eudema, 1991; Luis FlAQUer, "Familia y políticas públicas", en Anuario de la Facultad de Derecho de la Universidad Autónoma de Madrid, No 10, Madrid, 2006, pp. 268-281; Gerardo MeIl Landwerlin, La postmodernización de la familia española, Madrid, Acento, 1999 y VAlPuesta Fernández (n. 16), pp. 4.915-4.954.

${ }^{18}$ Rosario Valpuesta Fernández, "La encrucijada de la familia: entre la realidad social y el Derecho", en Juan Manuel Abril CAmpoy y María Eulalia Amat Llari (coords.) Homenaje al profesor Lluís Puig i Ferriol, Valencia, Tirant lo Blanch, 2006, vol. 2, pp. 2.415-2.421.

${ }_{19}$ Margarita A. Delgado, "Cambios recientes en el proceso de formación de la familia”, en Revista Española de Investigaciones Sociológicas, № 64, Madrid, 1993, pp. 123-153 y VAlpuesta Fernández (n. 16), pp. 4.932-4.953.

${ }^{20}$ Las funciones que tradicionalmente eran desempeñadas en el ámbito de lo privado por el grupo familiar van a ser asumidas por el ámbito de lo público. Esto viene motivado por el paso de un modelo liberal, en el que la intervención estatal en las relaciones familiares era mínima, a un modelo de Estado social y democrático de Derecho, en el que la protección de la institución familiar y del individuo se configura como una exigencia y un principio rector de la política social y económica. 
lograr un consenso en la redacción del artículo que contempla el derecho a casarse, por un lado, impidió el reconocimiento constitucional expreso de las parejas de hecho, pero, por otro, permitió la desvinculación del binomio tradicional familia-matrimonio ${ }^{21}$. Esta necesidad de acuerdo del constituyente hace que nos encontremos en ocasiones con una constitución con ambigüedades y contradicciones; y es esta ambigüedad la que, a la hora de interpretar la posible protección constitucional de la pareja de hecho, nos va a exigir una reconciliación entre la relevancia del matrimonio y el pluralismo de estructuras familiares existentes en la sociedad española ${ }^{22}$.

Respecto a qué familias están amparadas por el artículo 39 de la CE, lo cierto es que no hay una mención literal al matrimonio como único origen de la familia, sino que la familia puede surgir tanto dentro como fuera de él. Por lo que es legítima su protección con independencia de la existencia de un matrimonio previo ${ }^{23}$. La propia jurisprudencia del Tribunal Constitucional,

${ }^{21}$ Esta opción no es arbitraria y resulta esencial para contemplar la posible protección constitucional de la pareja de hecho como familia. En la Constitución española, la protección de la familia aparece desvinculada de la institución matrimonial, es decir, se separa la protección de la familia de la existencia de un matrimonio previo. Está opción no se adopta en otros países del entorno europeo que continúan vinculando el matrimonio y la familia. Es el caso de la Constitución italiana (art. 29.2: "El matrimonio se basa en la igualdad moral y jurídica de los cónyuges, dentro de los límites establecidos por la ley como garantía de la unidad familiar") o de la Ley Fundamental de Bonn (art. 29.2: "El matrimonio y la familia están bajo la protección particular del ordenamiento estatal”). Ambas figuras también aparecen vinculadas en el artículo 12 del Convenio Europeo para la Protección de los Derechos Humanos y de las Libertades Fundamentales que establece: "a partir de la edad núbil, el hombre y la mujer tienen derecho a casarse y a fundar una familia, según las leyes nacionales que rijan el ejercicio de este derecho". Sin embargo, el artículo 9 de la Carta de Derechos Fundamentales de la Unión Europea, permite la desvinculación entre ambas instituciones, protegiendo la familia no matrimonial en la medida que se encuentre protegida en los Estados miembros. Véase María Paz García Rubio, "Pareja de hecho y lealtad constitucional", en Teodora Felipa Torres García (coord.), Estudios de Derecho civil: homenaje al Profesor Francisco Javier Serrano García, Valladolid, Universidad de Valladolid, 2004, p. 38 y Blanca RodríGuez Ruzz, "Posición constitucional de las parejas de hecho", en Encarna RocA I TRÍAS et al., Estudio comparado de la regulación autonómica de las parejas de hecho: soluciones armonizadoras, Madrid, Consejo General del Poder Judicial, Manuales de Formación Continuada No 28, 2005, pp. 25-26.

A su vez, para un análisis del debate constitucional en esta materia véase Yolanda GómEz SÁnchez, Familia y Matrimonio en la Constitución de 1978, Madrid, Monografías del Congreso de los Diputados, 1990, pp. 244-245 y "Matrimonio y Familia: artículos 32 y 39 de la Constitución”, Revista de Derecho Político, No 36, Madrid, 1992, p. 215 y Artemi Rallo Lombarte, "Uniones conyugales de hecho y Constitución (la necesidad de clarificar la contradictoria jurisprudencia constitucional)", en Revista General de Derecho, No 606, Madrid, marzo, 1995, pp. 1.765-1.767.

${ }^{22}$ María Olga Sánchez MarTínez, "Constitución y pareja de hecho. El matrimonio y la pluralidad de estructuras familiares", en Revista española de Derecho Constitucional, N 58 , Madrid, enero-abril 2000, p. 61.

${ }^{23}$ Luis María DíEz-PicAzo, Sistema de Derechos Fundamentales, Madrid, Thomson-Civitas, 2003, p. 416. 
en la STC 222/1992, de 11 de diciembre, además de afirmar que dentro del concepto constitucional de familia se incluye el matrimonio sin descendencia, considera que la familia es un marco de solidaridades y dependencias que los poderes públicos tienen el deber de proteger, con independencia de su origen matrimonial o no ${ }^{24}$. Esta interpretación del Tribunal Constitucional confirma que en el sistema constitucional español no existe un modelo único de familia, sino que hay una pluralidad ${ }^{25}$. Luego, si la garantía institucional de la familia implica el respeto de sus rasgos esenciales (imagen maestra, esto es, la percepción social que se tenga de la familia en cada momento), entiendo que, actualmente, es posible afirmar que las parejas de hecho son una fuente de relaciones jurídico-familiares, al igual que el parentesco o el matrimonio ${ }^{26}$.

Respecto de la protección del derecho constitucional a contraer matrimonio y su relación con las parejas de hecho, el artículo 32 de la CE reconoce un derecho del individuo a casarse, pero a su vez garantiza la institución del matrimonio, el cual no deja de ser una entidad social basada en una especial relación vital entre las personas, por lo que quedará preservada siempre que se puedan reconocer los rasgos esenciales -imagen maestra- que de la misma tiene la conciencia social de cada tiempo y lugar ${ }^{27}$. A su vez, como derecho fundamental, permite plantearse tanto su faceta positiva -por la que una persona podrá ejercitar este derecho siempre que reúna los requisitos 18 legalmente establecidos-como su faceta negativa, consistente en no casarse cuando no lo desee. La faceta positiva de la libertad y el derecho a contraer matrimonio vienen determinados por la normativa matrimonial contenida en el Código Civil, que regula cuestiones esenciales como la capacidad para contraer matrimonio, con quién se puede contraer y cuál es el procedimiento adecuado para contraerlo. En dicha regulación, las prohibiciones se configuran como excepciones al principio de libertad, lo que condiciona tanto la aplicación como la interpretación de las mismas ${ }^{28}$.

${ }^{24}$ Véase Carmen Chinchilla Marín, "La familia en la jurisprudencia del Tribunal Constitucional”, en Aranzadi Civil, vol. I, Navarra, 1995, pp. 138-146 y Luis Dítz-PicAzo, "De quelque paradoxes dans la protection juridique des couples de fait en Droit espagnol", in Études ofertes à Jacqueline Rubellin-Devichi. Des concubinages: droit interne, droit internacional et droit comparé, Paris, Litec-Editions du JurisClasseur, 2002, pp. 417-418.

${ }^{25}$ Luis Díez- Picazo, Familia y Derecho, Madrid, Civitas, 1984, pp. 39-40.

${ }^{26}$ Julio V. Gavidia SÁnchez, La unión libre (el marco constitucional y la situación del conviviente supérstite), Valencia, Tirant lo blanch, 1995, pp. 43-48.

${ }^{27}$ García Rubio, María Paz, "La modificación del Código civil en materia de derecho a contraer matrimonio", La Ley, $\mathrm{N}^{\circ}$ 6359, Madrid, 15 de noviembre de 2005, vol. 5, ref. D-264, pp. 1121-1122.

${ }^{28}$ Véase, entre otros, F. Javier Gálvez Montes, "Comentario al artículo 32 CE”, en Fernando Garrido Falla, Comentarios a la Constitución, Madrid, Civitas, 1980, pp. 411-412; María del Rosario Valpuesta Fernández, "Matrimonio (D Civil)", en Enciclopedia Jurídica Básica, Madrid, Civitas, 1995, vol. III, pp. 4.204- 4.205. 
Por lo que se refiere a la faceta negativa del derecho a casarse, entiendo que es una manifestación del principio general de libertad y del derecho al libre desarrollo de la personalidad (art. 10.1 de la $\mathrm{CE})^{29}$. La salvaguarda de esta faceta negativa significa que el trato de favor al matrimonio no puede ser tal que colisione con el derecho de las personas a vivir en pareja sin estar casados o su derecho a permanecer soltero ${ }^{30}$. Sin embargo, no considero que de esta faceta negativa del derecho se derive la existencia de efectos jurídicos concretos -como el reconocimiento de derechos y deberes a todas las personas que no contraen matrimonio-; y tampoco creo que sobre ella se pueda legitimar la afirmación de que entre las personas que decidan no casarse no van a existir ni obligaciones, ni derechos ${ }^{31}$.

Para concluir esta perspectiva constitucional, hay que precisar que la jurisprudencia del Tribunal Constitucional sobre parejas de hecho es totalmente contradictoria, siendo difícil mantener al mismo tiempo las distintas soluciones y argumentos que se emplean en las dos principales sentencias: la que le deniega el reconocimiento del derecho a la pensión de viudedad (STC 184/1990, de 15 de noviembre) y la que reconoce el derecho a la subrogación en la vivienda arrendada (STC 222/1992, de 11 de diciembre). Estos selectivos cambios de criterio entre una y otra sentencia han sido criticados por la doctrina española, que señala las claras contradicciones valorativas del Tribunal Constitucional a la hora de estudiar uno u otro caso, estableciendo distintos grados de protección de la familia y resultando ésta más protegida en el ámbito privado que en el público ${ }^{32}$. De la argumentación del citado tribunal en estas sentencias parece inducirse que la equiparación entre las parejas de hecho y las parejas casadas es admisible cuando la vulneración del artículo 14 de la CE se produce entre particulares

${ }^{29}$ José Ramón de Verda y BEAmonte, "Principio de libre desarrollo de la personalidad y ius connubii (a propósito del ATC 222/1994)", en José María MarTinell y María Teresa Areces PiÑol (eds.), Uniones de hecho: XI Jornades Jurídiques Lleida, Universitat de Lleida, Facultat de Dret i Economia, Departament de Dret Privat, 1998, p. 488 y Gavidia Sánchez (n. 26), p. 76.

${ }^{30}$ Rodríguez Ruiz (n. 21), p. 30.

${ }^{31}$ Víctor Ferreres Comella, "El principio de igualdad y el "derecho a no casarse" (A propósito de la STC 222/1992)", en Revista Española de Derecho Constitucional, año 42, No 14 , Madrid, septiembre 1994, pp. 176-177 y Julio V. Gavidia SÁnchez, "La libertad de elección entre el matrimonio y la unión libre", en Derecho Privado y Constitución, No 12, Madrid, Centro de Estudios Políticos y Constitucionales, 1998, pp. 71-73.

${ }^{32}$ Entre otros, Rodrigo Bercovitz Rodríguez-Cano, "La pareja de hecho", en Aranzadi Civil, vol. I, Navarra, 1993, p. 1.836; Chinchilla Marín (n. 24), pp. 156-157; Verda y Beamonte (n. 29) pp. 481-482; A. Fernando Pantaleón Prieto, "Compañero/compañera", en Enciclopedia Jurídica Básica, Madrid, Civitas, 1995, vol. I, p. 1.161 y Encarna RocA TríAs, "Principi d'igualtat: matrimini i parella de fet (Comentari de la STC 184/1990, de 15 novembre)", en Revista Jurídica de Cataluña, vol. 90, No 2, Barcelona, 1991, p. 214. 
-como sucede en el caso de la subrogación arrendaticia-, pero no cabe esta equiparación ante la Administración, cuando lo que se solicita es una pensión de viudedad.

En realidad, en estas sentencias existen otro tipo de razones que justifican la distinta argumentación del Tribunal Constitucional y su aparente incoherencia. Así, se distingue entre dos tipos de razones, unas de fondo y otras de carácter institucional ${ }^{33}$. Dentro de las razones de fondo destacan los diferentes intereses que jurídicamente protegen cada una de las normas recurridas. La subrogación arrendaticia busca proteger el interés de una persona en continuar ocupando la vivienda en la que convivió con su pareja fallecida; mientras que la pensión de viudedad tiene como fin compensar el daño que supone la falta o la minoración de unos ingresos de los que se participaba en comunidad de vida con el cónyuge fallecido. En mi opinión, aunque la ratio legis de ambas normas es distinta, no está justificada la diversidad de soluciones por razones de fondo, porque, en esos términos, también en el caso del fallecimiento de la pareja, el conviviente supérstite ha de afrontar el mismo daño que el cónyuge viudo ${ }^{34}$.

Respecto a las razones institucionales, hay que tener presente el contexto político y social del que parten ambas sentencias. En primer lugar, la STC 184/1990 analiza una norma dictada tras la entrada en vigor de la 20 Constitución de 1978, mientras que la STC 222/1992 cuestiona una norma preconstitucional. En el primer supuesto, un legislador que había otorgado derechos a las parejas en otros campos decide no hacerlo en el ámbito de las pensiones de viudedad. En cambio, en el segundo supuesto, se trata de una norma previa a la Constitución que no concede un derecho a la subrogación arrendaticia a los convivientes ${ }^{35}$. Es cierto que una decisión favorable del Tribunal Constitucional respecto del reconocimiento de las pensiones de viudedad a las parejas de hecho habría tenido un claro impacto en los fondos públicos y hubiera podido generar una confrontación entre los poderes del Estado. Es por ello por lo que dicho tribunal, en virtud de estas razones institucionales, consideró lo más oportuno dejar que fuera el

${ }^{33}$ Ferreres Comella (n. 31), pp. 188-191.

${ }^{34}$ Lourdes Blanco Pérez-Rubio, Parejas no casadas y pensión de viudedad, Madrid, Editorial Trivium, 1992, pp. 54-55; María Luisa de la Flor FERnÁndez, Régimen jurídico de la pensión de viudedad, Sevilla, Mergablum. Edición y Comunicación, S. L., 2002, p. 179 y Lourdes López Cumbre, "Comentario al artículo 174 LGSS", en Luis Enrique de la Villa Gil, Ley General de la Seguridad Social, Comentarios, Jurisprudencia, Concordancias y Doctrina, Madrid, Colex. Editorial Constitucion y Leyes, S.A. 2004, p. 679.

${ }^{35}$ Eso sí, en el momento de dictar la sentencia existía un anteproyecto de nueva LAU donde sí que se contemplaba la extensión de la facultad subrogatoria a las parejas de hecho; anteproyecto que finalmente se convertiría en la ley vigente de arrendamientos urbanos en el ordenamiento español (Ley 29/1994, de 24 de noviembre, de Arrendamientos Urbanos). 
legislador el que tomara la decisión de llevar a cabo esta extensión de los beneficios sociales cuando estimase oportuno ${ }^{36}$.

A mi juicio, no existen razones jurídicas de fondo que permitan justificar las discrepancias existentes en estas sentencias en materia de parejas de hecho y, aunque, sin duda, el Tribunal Constitucional interviene en el debate público entre los distintos poderes del Estado, tampoco considero que las razones adecuadas para fundamentar sus sentencias deban ser, únicamente, las de carácter institucional, a pesar de que éstas se tengan en cuenta ${ }^{37}$.

\section{b) Perspectiva legislativa}

Junto a este panorama constitucional, el legislativo tampoco arroja mucha luz a la situación de los convivientes, pues esta materia en el ordenamiento jurídico español se caracteriza por la disparidad normativa vigente.

Por un lado, el legislador estatal no ignora este tipo de convivencias more uxorio, pero sólo las regula de manera fragmentaria, es decir, sólo contempla algunos efectos jurídicos de la convivencia en diversos cuerpos legales del ordenamiento, pero no desarrolla una regulación orgánica o global que otorgue a la pareja de hecho un estatuto legal propio ${ }^{38}$. Así, es posible citar la Ley 21/1987, de 11 de noviembre, que reconoce en su Disposición Adicional Tercera la capacidad para adoptar menores tanto a los cónyuges como a las parejas de hecho; la citada LAU 29/1994, de 24 de noviembre que, entre otros, en el artículo 16.1.b) contempla el supuesto de la subrogación para las uniones de hecho o el propio artículo 101 del $C C$, que señala como causa de extinción de la pensión fijada en los procedimientos de separación y divorcio (art. 97 del CC), la convivencia marital del beneficiario de dicha pensión con otra persona. Fuera del ámbito civil, sin lugar a dudas, conviene destacar la última referencia realizada por el legislador estatal en el artículo 174 de la Ley General de la Seguridad Social, reformado por la Ley 40/2007, de 4 de diciembre, de medidas en materia de seguridad social, donde se reconoce el derecho a la pensión de viudedad a algunos convivientes supérstites ${ }^{39}$.

${ }^{36}$ Según Víctor Ferreres Comella, lo que hay que cuestionarse es hasta qué punto un tribunal constitucional tiene que adoptar sus decisiones basándose en criterios institucionales y no en razones de fondo. Véase Ferreres Comella (n. 31), pp. 193-195.

${ }^{37}$ Luis Prieto Sanchís, Sobre principios y normas. Problemas del razonamiento jurídico, Madrid, Centro de Estudios Constitucionales, 1992, pp. 65-127 y Ernesto VIDAL GIL y María Teresa MARTín Morón, "Jurisprudencia y cambios legislativos: la equiparación del cónyuge y el conviviente more uxorio en la reciente doctrina del Tribunal Constitucional”, en Revista General de Derecho, No 586-587, Madrid, julio-agosto 1993, pp. 6.914-6.915.

${ }^{38}$ José L. Serrano Moreno, "Una propuesta para la tutela jurídica de la familia sin matrimonio (I)", en Revista Actualidad Civil, No 29, Madrid, 1987, p. 1.725.

${ }^{39}$ Otros ejemplos fuera del ámbito civil son el artículo 153 sobre delito de lesiones o el artículo 454 sobre encubrimiento, ambos en el Código Penal; el artículo 2.3.a) de la Ley 
Frente a esta dispersa regulación estatal, la situación es muy distinta en el ámbito autonómico. Por un lado, los legisladores de las comunidades autónomas en aquellos casos en los que cuentan con competencias en materia civil, intentan establecer un estatuto jurídico propio para estas relaciones lo más completo posible ${ }^{40} \mathrm{y}$, por otro, cuando no tienen estas competencias, pero a pesar de ello, por cuestiones de oportunidad política, las regulan, establecen un concepto funcional de pareja de hecho al que le reconocen unos efectos jurídicos muy limitados ${ }^{41}$. Todo ello me permite sostener que hoy en España hay casi tantas respuestas frente a los conflictos típicos que suscitan las parejas de hecho como comunidades autónomas existen.

Por último, dentro del ámbito local, también hallamos normas cuyo objetivo es dar publicidad de la existencia de estas parejas para facilitar o garantizar el reconocimiento de determinados efectos jurídicos a las mismas. Para ello, en primer lugar, se crean los registros municipales de parejas de hecho ${ }^{42} \mathrm{y}$, posteriormente, nacen los registros autonómi-

35/1995, de 11 de diciembre, de ayudas y asistencias a víctimas de delitos violentos y contra la libertad sexual; el artículo 11.2 de la Ley orgánica 5/1995, de 23 de mayo, reguladora del jurado; el artículo 3 de la Ley orgánica del procedimiento de Habeas Corpus o el artículo 93.1.1 ${ }^{\circ}$ de la Ley 22/2003, de 9 de julio, sobre la ley concursal que, a los efectos de la 22 clasificación de los créditos, entiende que son personas "especialmente relacionadas con el concursado", aquéllas que mantengan una relación de afectividad análoga a la conyugal y que hubieran convivido con el concursado dos años antes de la declaración del concurso.

${ }^{40}$ Estas legislaciones son, siguiendo un orden cronológico: la Ley 10/1998, de 15 de julio de Uniones Estables de Pareja de Cataluña; la Ley 6/1999, de 26 de marzo, de Parejas Estables no Casadas aprobada por las cortes de Aragón; la Ley 6/2000, de 3 de julio para la igualdad jurídica de las Parejas Estables de la Comunidad Foral Navarra; la Ley 18/2001, de 19 de diciembre, de Parejas Estables del Parlamento de Illes Balears; la Ley 2/2003, de 7 de mayo, de Parejas de Hecho del parlamento vasco y, finalmente, disposición adicional tercera de la Ley 2/2006, de 14 de junio de Derecho Civil de Galicia, que equipara los derechos y obligaciones forales de los convivientes a los de los cónyuges, modificada por la Ley 10/2007, de 28 de junio.

${ }^{41}$ Éste es el caso de la Ley 1/2001, de 6 de abril, de Uniones de Hecho en la comunidad valenciana; la Ley 11/2001, de 19 de diciembre, de Parejas de Hecho de la comunidad de Madrid; la Ley 4/2002, de 23 de mayo, de Parejas Estables del principado de Asturias; la Ley $5 / 2002$, de 5 de diciembre, de Parejas de Hecho del parlamento de Andalucía; la Ley 5/2003, de 6 de marzo, para la Regulación de las Parejas de Hecho de la comunidad autónoma de Canarias; la Ley 5/2003, de 20 de marzo, de Parejas de Hecho de la comunidad de Extremadura y de la Ley 1/2005, de 16 de mayo, de Parejas de Hecho de la comunidad autónoma de Cantabria.

${ }^{42}$ Entre todos ellos, he de destacar el primer registro municipal de pareja de hecho de Vitoria-Gasteiz, creado por el decreto de 28 de febrero de 1994 del ayuntamiento de Vitoria-Gasteiz, ya que sirvió de modelo para la creación de todos los posteriores registros municipales de parejas de hecho. Jaime Moreno Verdejo, "Algunas reflexiones sobre los registros municipales de uniones civiles no matrimoniales", en Revista General de Derecho, No 603, Madrid, diciembre 1994, pp. 12.545-12.546 y Carlos Villagrasa Alcaide, "Los registros municipales de uniones civiles", en José María Martinell y María Teresa Areces 
$\cos ^{43}$. Ambos son administrativos, destinados a facilitar la prueba de la existencia de una convivencia de hecho con unas determinadas características. Mediante la inscripción, los miembros de la pareja declaran la constitución, modificación y extinción de su relación, así como los contratos reguladores de sus relaciones personales y patrimoniales. Esta inscripción ampara a la pareja de hecho con una presunción iuris tantum sobre la existencia de una convivencia more uxorio a su favor, que puede ser desvirtuada por cualquier otro medio de prueba admitido en Derecho. He de decir que si lo que se pretende es que este tipo de relaciones afectivas tengan efectos no sólo inter partes sino, también, frente a terceros, el medio de prueba y publicidad idóneo en el ordenamiento español es la inscripción en el Registro Civil. Sin embargo, hoy, esta inscripción no es posible en España porque no existe una regulación de ámbito estatal sobre parejas de hecho que la determine y las comunidades autónomas no son competentes para disciplinar la inscripción en el mencionado registro (art. 149.1.8 ${ }^{\mathrm{a}}$ de la $\left.\mathrm{CE}\right)^{44}$.

Este panorama legislativo tan dispar no lo considero deseable y entiendo que es necesaria una intervención del legislador estatal. Dicho legislador no puede ignorar los conflictos típicos de las parejas de hecho, puesto que, como vimos, son situaciones familiares protegidas por el artículo 39 de la CE. Es cierto que este legislador no las ignora completamente y que está regulando aspectos concretos que les afectan, pero creo que lo hace de una forma muy tangencial. Además, el legislador estatal, al no contemplar la situación de la pareja de hecho de una forma conjunta y mantener una abstención legislativa en ciertas materias, está tolerando la invasión de sus competencias por parte de las comunidades autónomas, lo que contribuye de forma esencial al caos jurídico actual en esta materia en España, por lo

PIÑOL (eds.), Uniones de hecho: XIJornades Jurídiques Lleida, Universitat de Lleida, Facultat de Dret i Economia, Departament de Dret Privat, 1998, p. 517.

${ }^{43}$ Por orden cronológico de creación existen registros en las comunidades autónomas de: Asturias (decreto 71/1994 de 29 de septiembre); Valencia (orden de la Generalitat Valenciana de 15 de febrero de 1995); Madrid (decreto 36/1995 de 20 de abril); Andalucía (decreto 3/1996 de 6 enero); Extremadura (decreto 35/1997 de 18 de marzo); Castilla-La Mancha (decreto 124/2000, de 11 de julio); Castilla-León (decreto 117/2002, de 24 de octubre); Canaria (decreto 60/2004, de 19 de mayo); País Vasco (decreto 124/2004, de 22 de junio) y Cantabria (decreto 55/2006, 18 de mayo).

${ }^{44}$ Véase Alonso Herreros, Diego, "A propósito de los registros de uniones civiles de hecho", en Revista General de Derecho, N 678-679, Madrid, marzo-abril 2001, pp. 1.844-1.852 y Patricia LóPez Peláez, "Registros administrativos de parejas de hecho: incidencia en ellos de la nueva regulación del matrimonio", en Carlos Lasarte Álvarez, Fátima Yáñez Vivero, Araceli Donado Vara, María Fernanda Moretón SAnz (coords.), Familia, matrimonio y divorcio en los albores del siglo XXI, Madrid, UNED, IDADFE y El Derecho, 2006, p. 370. 
que creo merece un severo reproche ${ }^{45}$. Ahora bien, también soy consciente de que la opción reguladora del estatuto jurídico de la pareja de hecho tiene numerosos detractores, porque se entiende que una regulación de estas características vulneraría el principio del libre desarrollo de la personalidad de los individuos para entablar relaciones personales y afectivas (artículo 10 de la $\mathrm{CE}$ ), sobre todo si esta regulación se asemeja a la matrimonial ${ }^{46}$.

En mi opinión, como regla general, no se puede afirmar que el principio del libre desarrollo de la personalidad y la libre elección de no casarse se vulneran siempre que a ciertos conflictos de la convivencia more uxorio se le apliquen determinadas normas matrimoniales. El matrimonio es una relación jurídica que se basa, para su regulación, en el desarrollo de la vida en pareja, a la que configura como institución jurídica. Las parejas de hecho no constituyen la institución jurídica matrimonial, pero sí establecen esa relación afectiva de la vida en pareja que sirve de soporte a la regulación matrimonial. Por ello, considero que pueden aplicarse a las parejas de hecho aquellas normas de resolución de determinados conflictos matrimoniales, cuyo fundamento sea precisamente esa convivencia more uxorio.

\section{EL CONCEPTO DE CONVIVIENTE SUSPÉRSTITE}

Además de esta breve reflexión sobre la determinación de cuáles son los fundamentos que justifican el reconocimiento de efectos jurídicos a las parejas de hecho y su regulación actual, es oportuno precisar a qué nos referimos cuando hablamos de "pareja de hecho".

${ }^{45}$ En este sentido, María Paz García Rubio analiza el problema de la lealtad constitucional y la regulación de las parejas de hecho y considera que, aunque el legislador estatal está incurriendo en una violación de la norma de lealtad constitucional con su silencio legislativo respecto de las materias en las que tiene competencias exclusivas, resulta muy complicado su posible control jurídico al no existir en el ordenamiento español una regulación clara sobre la inconstitucionalidad por omisión, véase GARCía Rubio (n. 21), pp. 49-58.

${ }^{46}$ Son contrarios a esta regulación, entre otros, Federico J. CANTERo NúÑEz, "Reflexiones en torno a la pretendida regulación de las uniones de hecho", en Revista de Derecho Privado, año 79, No 3, Madrid, marzo 1995, p. 224; Teresa CERVERA Soto, "Breves reflexiones sobre la regulación jurídica de las uniones no matrimoniales", en Revista de Derecho Privado, año 84, No 3, Madrid, 2000 (I), pp. 218-220; Manuel Gitrama GonZÁlez, "Notas sobre la problemática jurídica de la pareja no casada", en VV.AA. Libro Homenaje al Profesor José Beltrán de Heredia y Castaño, Salamanca, Ediciones de la Universidad de Salamanca, Publicaciones del departamento de Derecho Civil, 1984, pp. 246-247; Carlos Martínez de Aguirre, "Las uniones de hecho: Derecho aplicable (I)", en Revista Actualidad Civil, No 4, Madrid, 1999, p. 1.110 o A. Fernando PAntaleón Prieto, "El régimen jurídico civil de las parejas de hecho", en José María Martinell y María Teresa Areces PIÑol (eds.), Uniones de hecho: XI Jornades Jurídiques Lleida, Universitat de Lleida, Facultat de Dret i Economia, Departament de Dret Privat, 1998, pp. 73-74. 
La pareja o la convivencia de hecho que puede ser objeto de reconocimiento de efectos jurídicos por parte del ordenamiento no responde a un único concepto legalmente establecido. No obstante, cuando se habla de pareja de hecho o de unión de hecho se está haciendo referencia a convivencias more uxorio y no a otras convivencias de ayuda mutua o de acogimiento de personas mayores, donde el elemento subjetivo del afecto no es lo primordial, sino que lo esencial es la existencia de una comunidad de vida entre sus miembros. En efecto, como vamos a estudiar a continuación, la jurisprudencia, la mayoría de la doctrina y la regulación autonómica han optado por contemplar sólo un modelo de relaciones afectivas similares a las matrimoniales, restringiendo el concepto de convivencia de hecho al que van a reconocer efectos jurídicos ${ }^{47}$. Por ello, voy a seguir esta tendencia mayoritaria y, en relación con la problemática de los derechos sucesorios, exclusivamente, me voy a centrar en las parejas de hecho en este sentido restringido.

\section{El concepto normativo de pareja de hecho}

En un primer momento, tanto en los reconocimientos parciales de la legislación estatal como en las primeras resoluciones judiciales ${ }^{48}$, se evita definir de forma explícita la pareja de hecho. Para ello, se emplean fórmulas genéricas como "relación de afectividad análoga a la conyugal", "convivencia more uxorio" o "vivir maritalmente con otra persona". Por su parte, las regulaciones de los registros de parejas de hecho son las primeras que determinan un concepto explícito de pareja objeto de reconocimiento jurídico y lo hacen mediante el establecimiento de unos requisitos para proceder a su inscripción en los mismos ${ }^{49}$. Luego, durante esta primera fase, no existe

${ }^{47}$ Sobre el concepto restringido de pareja de hecho, véase Diego Espín CÁnOvas, "Familia no matrimonial", en José Luis Lacruz Berdejo (presidente), Ponencias del Congreso Hispanoamericano de Derecho de Familia, Cáceres, Plasencia y Trujillo, s.e., No 36, 1987, p. 24; Eduardo Estrada Alonso, La unión extramatrimonial en el Derecho civil español, $2^{\mathrm{a}}$ ed., Madrid, Civitas, 1991, p. 76; Ignacio Gallego Domínguez, Las parejas no casadas y sus efectos patrimoniales, Madrid, Centro de Estudios Registrales, 1995 p. 48; Gitrama González (n. 46), p. 210 y Carolina Mesa MARRERO, Las uniones de hecho: análisis de las relaciones económicas y sus efectos, $3^{\mathrm{a}}$ ed., Navarra, Thomson-Aranzadi, 2006, pp. 45-46.

${ }_{48}$ Natalia Álvarez Lata, "Las parejas de hecho: perspectiva jurisprudencial”, en Derecho privado y Constitución, Nº 12, Madrid, 1998, pp. 8-17 y Magda TORRERo Muñóz, "La jurisprudencia del Tribunal Supremo y del Tribunal Constitucional ante las uniones de hecho", en Revista General de Derecho, No 648, Madrid, septiembre 1998, pp. 10.625-10.642.

${ }^{49}$ Las normas reguladoras de la mayoría de los registros municipales existentes establecen el carácter voluntario de la inscripción. Los miembros de la pareja de hecho que pretenden inscribirse tanto heterosexuales como homosexuales, han de acreditar ante el encargado del registro municipal cinco requisitos esenciales de acceso: ser mayor de edad 
un concepto homogéneo de pareja de hecho, porque no nos encontramos ante una regulación del estatuto jurídico de estas convivencias more uxorio por parte del ordenamiento estatal, sino sólo ante reconocimientos puntuales de efectos jurídicos a ciertas convivencias que son tomadas como presupuestos de aplicación de una norma concreta ${ }^{50}$.

Como ejemplos concretos de los distintos conceptos de pareja de hecho empleados por el legislador estatal es oportuno citar la Ley 29/1994, de 24 de noviembre de Arrendamientos Urbanos. Según esta norma para que proceda la subrogación del conviviente en los casos de desistimiento y muerte de su pareja arrendataria [arts. 12 y 16.1.b)], la convivencia con ésta tendrá que haber sido de forma permanente en análoga relación de afectividad a la de cónyuge, con independencia de su orientación sexual, durante, al menos, los dos años anteriores o al desistimiento o abandono, o al tiempo del fallecimiento, salvo que hubieran tenido descendencia en común, en cuyo caso bastará la mera convivencia ${ }^{51}$. Sin embargo, el último concepto de pareja de hecho establecido en el artículo 174 Ley General de la Seguridad Social, tras la reforma de 2007, es distinto. De nuevo, la estabilidad de la convivencia en el momento del fallecimiento y la acreditación de la estabilidad de la comunidad de vida son esenciales y básicas para entender que la pareja es susceptible de protección, pero 26 ahora la existencia de descendencia en común no se tiene en cuenta y la duración mínima de la convivencia previa al fallecimiento ha de ser de cinco años para que proceda el otorgamiento de la prestación de viudedad al conviviente supérstite ${ }^{52}$.

o menor emancipado; no tener entre sí relación de parentesco o adoptiva en línea recta o colateral de segundo grado; no encontrarse incapacitado para emitir el consentimiento necesario para llevar a cabo este tipo de declaración de voluntad; no estar sujeto a vínculo matrimonial y no estar inscrito como integrante de otra pareja de hecho en otro registro similar. Véase Villagrasa Alcaide (n. 42), pp. 520-522.

${ }^{50}$ Elda García-Posada Gómez, "El concepto de convivencia no matrimonial en Derecho español”, en Anuario de Derecho Civil, tomo LVI, fascículo III, Madrid, julio-septiembre 2003, pp. 1.046-1.047.

${ }^{51}$ Véase Ángel Carrasco Perera, “Comentario al artículo 16 LAU”, en Rodrigo Bercovitz Rodríguez-Cano, Comentarios a la Ley de Arrendamientos Urbanos, Navarra, Aranzadi, 2002, p. 373; Patricia Estelles Peralta, "Parejas de hecho y subrogación en el arrendamiento", en Revista General de Derecho, No 637-638, Madrid, octubre-noviembre 1997, pp. 12.093-12.096; Juan V. Fuentes Lojo, Novísima Suma de Arrendamientos Urbanos, adaptada a la nueva LEC de 7 de enero de 2000 en lo procesal y al día en el ámbito doctrinal y jurisprudencial en lo sustantivo, Barcelona, Bosch, 2001, tomo I, p. 160 y José Pérez de VARGas MuÑoz, La subrogación de la vivienda arrendada y las parejas de hecho (Estudio jurisprudencial y doctrinal), Madrid, Editorial Complutense, 1995, pp. 242-253.

${ }^{52}$ Lo anteriormente expuesto pone de manifiesto que el concepto de pareja de hecho que ha establecido la Ley General de la Seguridad Social para el reconocimiento de la pensión de viudedad es más restringido que el existente en las comunidades autónomas con Derecho 
Por su parte, en todas y cada una de las legislaciones autonómicas se hace referencia a los requisitos que han de estar presentes en la relación de afectividad para que ésta pueda ser calificada como "pareja de hecho" susceptible de reconocimiento de efectos jurídicos. Todas regulan tanto las parejas heterosexuales como homosexuales ${ }^{53}$. Como regla general, se exige la convivencia estable durante un período determinado, aunque en la mayoría de estas normas para acreditar su existencia basta con que haya descendencia común o con la constitución de la pareja mediante un documento público ${ }^{54}$. En otros supuestos no basta con la convivencia estable, sino que la inscripción en el registro autonómico correspondiente es un requisito constitutivo para que resulte de aplicación la norma ${ }^{55}$. Todas ellas califican la relación de afectividad entre los miembros de la pareja como una relación de afectividad análoga a la conyugal. Por este motivo contemplan entre los límites o impedimentos para constituir válidamente este tipo de relaciones de hecho, el parentesco ${ }^{56}$, el matrimonio o la unión estable anterior ${ }^{57}$.

Civil propio, por lo que puede suceder que parejas de hecho que tengan reconocidos efectos jurídicos en una de estas comunidades, no sean consideradas como tales en el ámbito estatal a la hora de serle atribuida la pensión de viudedad al conviviente supérstite.

${ }^{53}$ La ley catalana fue la primera que reguló la convivencia homosexual. En el momento de su aprobación, la constitucionalidad de esta norma se cuestionó porque se entendía que instaura un nuevo tipo de matrimonio entre personas del mismo sexo. Véase Martín GARCíARipoll Montijano, "Equiparación entre parejas de hecho heterosexuales al matrimonio, y equiparación de parejas heterosexuales de hecho a las homosexuales", en Aranzadi Social, vol. III, Navarra, 1998, pp. 2.584-2.585.

${ }^{54}$ En las primeras regulaciones autonómicas se exigía que la convivencia estable fuera por un período ininterrumpido de dos años (arts. 1 y 19 de la norma catalana, art. 3 de la norma aragonesa), pero a partir de la legislación navarra (art. 2.2) el período de convivencia se redujo a un año y así se consolidó en otras regulaciones posteriores [art. 1 de la norma valenciana, art. 1 de la madrileña, art. 3.2 de la asturiana, art. 1 de la canaria, art. 2.2 de la extremeña, art. 4.3.a) de la cántabra y disposición adicional tercera de la Ley 2/2006, de 14 de junio, de Derecho Civil de Galicia]; aunque otras normas autonómicas optaron, directamente, por eliminar la exigencia de un plazo determinado de convivencia (art. $1 \mathrm{de}$ la norma balear, art. 3 de la andaluza y art. 2.1 de la vasca).

${ }^{55}$ Se contempla la inscripción constitutiva en la regulación valenciana (art. 1.2); balear (art. 1.2); madrileña (art. 3.1); extremeña (art. 2.3); vasca (art. 3.1) y cántabra (art. 6.1).

${ }^{56}$ En todas las leyes, el parentesco en línea recta por consanguinidad o adopción en cualquier grado es un impedimento. También existe este límite respecto de la línea colateral, pero mientras que en las leyes aragonesa, navarra, asturiana, andaluza, vasca y cántabra sólo es hasta el segundo grado; en la valenciana, balear, madrileña, canaria y extremeña se amplia hasta el tercer grado, al igual que en la regulación matrimonial. En Cataluña y en Galicia, directamente, se exige para que la constitución de la pareja sea válida que los sujetos no concurra en ninguno de los impedimentos matrimoniales.

${ }^{57}$ En Aragón, Navarra, Madrid y Asturias es suficiente para que no pueda inscribirse y serle de aplicación la ley que uno de los miembros de la pareja se encuentre unido de hecho; mientras que en Baleares y Andalucía sólo es impedimento cuando uno de lo miembros 


\section{El concepto jurisprudencial de pareja de hecho}

Vistos los conceptos de la regulación estatal y autonómica, dentro de la jurisprudencia hay que destacar la STS de 18 de mayo de 1992, donde considera que la pareja de hecho susceptible de reconocimiento de efectos jurídicos es aquélla cuya

"convivencia more uxorio ha de desarrollarse en régimen convivencial de coexistencia diaria, estable, con permanencia temporal consolidada a lo largo de los años, practicada de forma externa y pública con acreditadas actuaciones conjuntas de los interesados, creándose así una comunal vida amplia, intereses y fines, en el núcleo de un mismo hogar" 58 .

Los posteriores pronunciamientos jurisprudenciales inciden en destacar como notas distintivas de la convivencia de hecho: la estabilidad, la permanencia, la continuidad y la publicidad de la misma ${ }^{59}$.

\section{Opinión crítica}

Hay que destacar que, si bien parece que la jurisprudencia y la regulación, sobre todo la autonómica, optan por un mismo concepto restringido de pareja de hecho, en realidad, existe una importante diferencia. La jurisprudencia lo que intenta es la normalización de determinadas situaciones de convivencia de hecho mediante el reconocimiento de unos efectos jurídicos, cuando a priori se constate la concurrencia de una serie de requisitos. Por su parte, las distintas regulaciones autonómicas -en la medida en que sus competencias lo permiten- lo que buscan es la institucionalización de las parejas de hecho que reúnan ciertos requisitos, para que les sea de aplicación

ya está inscrito en algún registro. Otras legislaciones como la madrileña, la canaria, la extremeña, la vasca y la cántabra, añaden a estos impedimentos referencias relativas a la necesaria capacidad de los miembros de la pareja.

${ }^{58}$ STS de 18 de mayo de 1992 [RJ1992, 4907]. Véase Vicente EsPert SANZ, "Comentario a la STS de 18 de mayo de 1992", en Revista General de Derecho, No 753-574, Madrid, julioagosto 1992, p. 6.922 .

${ }^{59}$ Véase la STS de 4 de junio de 1998 [RJ 1998, 3722], que introduce la idea de la creación de vínculos familiares a raíz de la convivencia. Idea que está presente en una de las primeras sentencias de la "jurisprudencia menor" sobre parejas de hecho, SAP Córdoba de 21 de abril de 1986 [La Ley, tomo II, Madrid, 1986, ref. 6400]. Igualmente, véase, entre otras, SAP Sevilla de 31 de mayo de 2000 [ $A C$, 2000, 2458]; SAP Pontevedra de 22 de mayo de 2001 [AC, 2001, 1866]; SAP Córdoba de 13 de noviembre de 2001 [UUR, 2001, 20505] o SAP Lugo de 14 de junio de 2002 [UUR, 2002, 211564]. 
el modelo de convivencia regulado en dichas autonomías ${ }^{60}$. Eso sí, a pesar de esta diferencia funcional de la definición de la pareja de hecho, para normalizar o para crear una institución jurídica, los requisitos que se tienen en cuenta son similares, ya que ambas tienden a establecer un concepto restringido de pareja de hecho basado en el modo de vida conyugal.

En mi opinión, una pareja de hecho es aquélla compuesta por dos personas sin vínculo de parentesco próximo, de igual o de distinto sexo, que gozan de madurez o capacidad sicológica necesaria para convivir de modo semejante al matrimonial y que establecen entre ellos una comunidad de vida y afectos acompañada, en su caso, de la puesta en común de determinados recursos económicos. Además, esta comunidad de vida está calificada por una estabilidad, exclusividad y notoriedad, y por una affectio maritalis, que implica una convivencia con una dimensión sexual que se presupone.

Por lo tanto, la pareja de hecho como opción de convivencia more uxorio difiere del matrimonio en algunos aspectos esenciales. Por ejemplo, los convivientes no asumen un vínculo formal por el que automáticamente se les reconozcan una serie de derechos y obligaciones; tampoco han de acudir a un procedimiento judicial para que se determine la disolución de la relación y, como regla general, su convivencia no goza de un reconocimiento de los efectos jurídicos oponibles frente a los terceros. En este sentido, creo que merece una crítica el concepto de pareja de hecho que han regulado las comunidades autónomas, pues establecen un concepto institucionalizador que crea un nuevo estatus jurídico: el de la pareja registrada o formalizada, distinto de la pareja de hecho. Considero que lo más oportuno es el empleo, tal y como lo hace la jurisprudencia, de un concepto instrumental de pareja de hecho, puesto que éste se corresponde más con un modelo de convivencia puramente fáctico.

\section{LOS DERECHOS SUCESORIOS DEL CONVIVIENTE SUPÉRSTITE en el Derecho Civil común}

Ante la ausencia de una regulación estatal respecto de los derechos sucesorios del conviviente supérstite, estimo que lo más oportuno es determinar, en primer lugar, qué respuesta se está dando por parte de los tribunales -cuando resulte de aplicación el Derecho Civil común ${ }^{61}$ - en los supues-

${ }^{60}$ Véase García-Posada Gómez (n. 50), pp. 1.048-1.049.

${ }^{61}$ De nuevo, hay que recordar que en España es preciso tener presente en el estudio de esta materia la ausencia de una norma estatal y la existencia de múltiples disposiciones autonómicas. En el presente artículo no se va a analizar la regulación autonómica en materia de derechos sucesorios, sino que el estudio se va a centrar en determinar cuál es la solución 
tos de disolución de las parejas de hecho por fallecimiento de uno de los convivientes y, en segundo lugar, poder exponer la que considero es la vía más adecuada dentro del ordenamiento para proceder a la atribución de derechos sucesorios a los convivientes de hecho.

\section{Las soluciones jurisprudenciales ante la ausencia de una regulación estatal}

El reconocimiento de derechos sucesorios al conviviente supérstite es un asunto que escasamente se ha planteado ante los tribunales españoles. Se han señalado varias razones que pueden justificar esta ausencia, como que este reconocimiento de derechos sucesorios se puede conseguir acudiendo a la vía testamentaria para instituir como heredero al conviviente; que la atribución de derechos sucesorios al propio cónyuge ha sido una conquista bastante tardía, por lo que en mayor medida lo será para las relaciones de hecho, o que la dificultad para lograr este reconocimiento motiva la renuncia a su planteamiento ante los tribunales ${ }^{62}$. No obstante, lo cierto es que éstos sí que han tenido que pronunciarse en supuestos donde la ruptura de la convivencia de hecho se produce por el fallecimiento de uno de los miembros de la pareja.

que se considera más ajustada a Derecho en aquellos casos en los que se carece de una disposición normativa al respecto. No obstante, quiero dejar apuntado que considero que esta regulación autonómica se puede sistematizar en dos grupos claramente diferenciados. El primero, lo constituyen todas las comunidades con competencias para regular en materia civil, puesto que la mayoría de ellas cuentan con previsiones específicas sobre los derechos sucesorios de las parejas de hecho. Es el caso, con ciertos matices, de Cataluña, Aragón, Navarra, Baleares, País Vasco y Galicia. El segundo grupo lo forman las restantes comunidades autónomas que cuentan con regulación de parejas de hecho, por orden cronológico son: Valencia, Madrid, Asturias, Andalucía, Canarias, Extremadura y Cantabria. Estas últimas comunidades citadas cuentan con leyes de parejas de hecho, a pesar de que no tienen competencias en materia civil, luego, jurídicamente hablando, es evidente que carecen de competencias para regular las cuestiones relativas a los derechos sucesorios del conviviente supérstite. Por este motivo entiendo que este segundo grupo en materia sucesoria no sólo esta constituido por estas comunidades sino por todas las comunidades autónomas que se encuentran sometidas al Derecho Común, tengan o no regulación de parejas de hecho. Véase para un estudio detallado de esta regulación, Susana Espada Mallorquín, Los derechos sucesorios de las parejas de hecho, Navarra, Thomson-Civitas, 2007.

${ }^{62}$ José A., Martín PÉrez, "Convivencia y herencia. Derechos sucesorios en las uniones de hecho”, en Ramón Herrera Campos (coord.), Homenaje al profesor Bernardo Moreno Quesada, Almería, Universidad de Almería, Servicio de Publicaciones, 2000, vol. II, pp. 1.091-1.092 y Salvador TorRes Escámez, "La sucesión mortis causa del conviviente more uxorio", en Ramón Herrera Campos (coord)., Parejas de hecho: curso de Verano de la Universidad Complutense en Almería, Granada, Publicaciones de la Real Academia Granadina del Notariado, 1996, p. 122. 
Las soluciones que ha adoptado el Tribunal Supremo en estos casos se pueden clasificar en dos grandes bloques. En primer lugar, están los supuestos en los que, tras el fallecimiento de uno de los miembros, el conviviente supérstite sólo reclama frente a los herederos abintestato que se liquide la sociedad o la comunidad de bienes que mantenía con el causante [a)] y, en segundo lugar, los supuestos en los que el conviviente considera que la ruptura por el fallecimiento ha generado una situación de enriquecimiento injusto que debe ser compensada mediante la aplicación del llamado principio de protección del conviviente más perjudicado por la ruptura, que impide que un miembro de la pareja se beneficie del otro injustificadamente por el mero hecho de iniciar una relación more uxorio [b)].

\section{a) La solicitud tras el fallecimiento de la liquidación}

\section{del régimen económico existente durante la convivencia}

Los supuestos que han llegado al Tribunal Supremo donde la ruptura de la pareja de hecho se produce por el fallecimiento de uno de los convivientes son escasos. En la mayoría de ellos, la solicitud por parte del conviviente supérstite frente a los herederos del causante no tiene por objetivo su declaración como heredero abintestato y mucho menos como legitimario en la herencia de su compañero fallecido, sino que se limita a pedir la liquidación de los intereses económicos generados durante la convivencia, mediante la disolución de la sociedad o comunidad de bienes existente con el fallecido hasta el día de su muerte. Las pretensiones de dicha liquidación van desde la aplicación analógica de las normas de la sociedad de gananciales, pasando por la consideración de la existencia de una sociedad irregular o de ganancias entre las partes, a la acreditación de una comunidad de bienes. La ausencia de una regulación expresa sobre esta cuestión en el ámbito estatal, obliga al Tribunal Supremo a decidir dependiendo de las circunstancias concretas de cada caso y, puesto que el conviviente supérstite no plantea la posibilidad de su llamamiento a la sucesión intestada, cuando no se ve satisfecha la liquidación del régimen patrimonial solicitada, no obtiene el reconocimiento de ningún otro derecho tras la ruptura por fallecimiento de su pareja.

En primer lugar, se pueden mencionar los supuestos en los que el conviviente reclama frente a los herederos abintestato que se liquide la sociedad de gananciales que éste mantenía con el causante. Éste es el caso de la STS de 22 de julio de $1993^{63}$, donde la conviviente supérstite, tras el fallecimiento de su pareja, interpone demanda pretendiendo que se le reconozca su derecho a la mitad de los bienes adquiridos durante su convivencia y fundamenta su pretensión en la aplicación analógica de las normas de la

${ }^{63}$ STS de 22 de julio de 1993 [RJ, 1993, 6274]. 
sociedad de gananciales o, en su defecto, en las que disciplinan la sociedad irregular. El tribunal desestima la pretensión de la actora, porque considera que no es posible la aplicación analógica del citado régimen económicomatrimonial a los convivientes de hecho ${ }^{64}$. Posteriormente, en la STS de 4 de marzo de 1997, en un caso similar al anterior ${ }^{65}$, también se desestimó la liquidación del régimen patrimonial de la convivencia mediante la aplicación analógica del régimen de gananciales, porque se consideró que esta aplicación analógica de un régimen matrimonial es contraria a la voluntad de los propios convivientes que inician este tipo de relación de hecho ${ }^{66}$. En ambos casos, el conviviente supérstite no se plantea la posibilidad de su llamamiento a la sucesión intestada de su pareja fallecida y, al no verse satisfecha la liquidación del régimen patrimonial por vía del régimen económico de gananciales, el tribunal no reconoce ningún otro derecho tras la ruptura de la pareja por fallecimiento.

En segundo lugar, sobre la posibilidad de considerar que existe una sociedad irregular entre los convivientes, cabe mencionar la STS de 18 de marzo de $1995^{67}$, ya que en este caso se acreditó la convivencia de una pareja de hecho como si de un matrimonio se tratara y se constató que durante su prolongada relación habían realizado juntos diversas actividades industriales, así como la adquisición conjunta o individual de bienes para la sociedad surgida de su unión. El Tribunal Supremo apreció la existencia entre los convivientes de "una sociedad civil irregular de carácter universal que de acuerdo con el art. 1669.2 CC habrá de referirse a las disposiciones relativas a la comunidad de bienes (art. 392 y ss. CC)" (fundamento jurídico $3^{\circ}$ ), procediéndose a su liquidación en este sentido.

Finalmente, nos encontramos con los supuestos en los que se solicita la declaración y liquidación de una comunidad de bienes. En este sentido, se manifiesta la STS de 21 de octubre de $1992^{68}$. En el fundamento jurídico $5^{\circ}$ de la misma se afirma que por el mero hecho de convivir como pareja de hecho, no es posible establecer una presunción general de comunidad de bienes para estas relaciones de pareja, siendo necesario que se aprecie una voluntad manifiesta de hacer comunes todos o algunos de los bienes

${ }^{64}$ Véase Rosario Valpuesta Fernández, “Comentario a la STS de 22 de julio de 1993”, en Cuadernos Civitas de Jurisprudencia Civil, No 33, Madrid, 1993, pp. 889-990.

${ }^{65}$ Según los hechos probados de esta sentencia, tras ocho años de convivencia, uno de los miembros de la pareja de hecho fallece en un accidente de tráfico. En ese momento se declara como única heredera abintestato a la madre del fallecido y la conviviente inicia el proceso para que se lleve a cabo la disolución de la pretendida sociedad de gananciales que mantuvo con el causante constante su convivencia.

${ }^{66}$ Véase el fundamento jurídico $7^{\circ}$ de la STS de 4 de marzo de 1997 [RJ, 1997, 1640].

${ }^{67}$ STS de 18 de marzo de 1995 [RJ, 1995, 1962].

${ }^{68}$ STS de 21 de octubre de 1992 [RJ, 1992, 8590]. 
adquiridos durante su relación. Posteriormente, en la STS de 22 de enero de 2001, de nuevo, tras el fallecimiento de uno de los convivientes, el supérstite solicita a los herederos la liquidación de la comunidad de bienes existente entre él y el causante. En este caso, el Tribunal Supremo entiende que la existencia de tal comunidad no queda probada, ya que la adquisición de un inmueble durante una unión more uxorio en escritura pública en la que el comprador es sólo un conviviente no permite afirmar que dicho inmueble sea común a la pareja, teniendo que acreditar que el dinero para su adquisición era de ambos. En estos supuestos, el Tribunal Supremo parte de una presunción de independencia patrimonial entre las partes, salvo prueba en contrario $^{69}$. Para concluir, en la STS de 27 de mayo de $2004^{70}$, el tribunal sostiene que no se ha acreditado que hubo comunidad, porque, a pesar de que en su convivencia "hubiera actos comunes de disposición, también consta que no hubo voluntad expresa o tácita de hacer comunes todos los bienes adquiridos (la cursiva es mía)" (fundamento jurídico $3^{\circ}$ ).

Luego, el principal problema que plantean estas soluciones jurisprudenciales en los casos de ruptura por fallecimiento, es la necesidad de probar la existencia de una comunidad de bienes o de una sociedad de ganancias que desvirtúe la presunción de independencia patrimonial que rige en la liquidación del patrimonio que surge del desarrollo de la convivencia de hecho $^{71}$. En ausencia de pacto, la carencia de una regulación estatal sobre la liquidación de las relaciones patrimoniales de estas parejas supone que, salvo prueba en contrario, se entenderá que existe una independencia patrimonial entre las partes a la hora de liquidar. A esto se une la ausencia absoluta de reconocimiento de derechos sucesorios ex lege, lo que impide que, en estos casos, ciertas previsiones legales sucesorias puedan servir como un mecanismo corrector que mitigue los desequilibrios patrimoniales que esta presunción general de separación de patrimonios puede llegar a producir en los supuestos de disolución de la convivencia por fallecimiento ${ }^{72}$.

${ }^{69}$ Véase el fundamento jurídico $2^{\circ}$ de la STS de 22 de enero de 2001 [RJ, 2001, 1678].

${ }^{70}$ STS de 27 de mayo de 2004 [RJ, 2004, 3577].

${ }^{71}$ Son numerosas las sentencias de las audiencias provinciales en este sentido. Podemos destacar, entre otras, SAP Madrid 29 de abril de 1992 [RGD, № 579, pp. 12.058-12.060]; la SAP Málaga de 23 de abril de 1997 [ $A C, 1997,1003]$; SAP Barcelona de 18 de febrero de 1998 [AC, 1998, 282]; SAP Lugo de 1 de abril de 2005 [JUR, 2005, 130545]; SAP Alicante de 14 de septiembre de 2005 [UUR, 2006, 3684] y SAP Murcia de 15 de noviembre de 2006 [UUR, 2007, 14591].

72 Véase Fernando Crespo Allué, "Comentario al nuevo artículo 834 del Código civil”, en Vicente GuILARTe GutiérRez y otros, Comentarios a la reforma de la separación y el divorcio, Valladolid, Lex Nova, 2005, p. 239 y Ángel Luis Rebolledo VARela, Separación de bienes en el matrimonio (el régimen convencional de la separación de bienes), Madrid, Editorial Montecorvo, 1983, pp. 50-51. 


\section{b) La aplicación de la doctrina del enriquecimiento injusto y del llamado principio de protección del conviviente perjudicado por la ruptura}

Dentro del análisis de la respuesta jurisprudencial en los casos de ruptura por fallecimiento de un miembro de la pareja de hecho, por el momento, existen dos sentencias que son esenciales: la STS de 17 de junio de $2003^{73}$ y la STS de 23 de noviembre de $2004^{74}$. El Tribunal Supremo en estos casos $\mathrm{y}$, ante la ausencia de una regulación expresa, ha empleado la doctrina del enriquecimiento injusto ${ }^{75}$ y del llamado principio de protección del conviviente más perjudicado por la ruptura, como medios idóneos para reconocer efectos jurídicos a la ruptura de la convivencia por fallecimiento de uno de los miembros de la pareja ${ }^{76}$.

En la STS de 17 de junio de $2003^{77}$, como solución al problema de la compensación de las consecuencias económicas negativas que sufre el conviviente supérstite tras el fallecimiento de su pareja estable, el tribunal

${ }^{73}$ STS de 17 de junio de 2003 [RJ, 2003, 4605].

${ }^{74}$ STS de 23 de noviembre de 2004 [RJ, 2004, 7485].

${ }^{75}$ La STS de 11 de diciembre de 1992 [RJ, 1992, 9733] fue la primera sentencia del Tribunal Supremo que admitió la aplicación de este principio para atender a las reclamaciones patrimoniales de los convivientes de hecho.

$34{ }^{76}$ Dentro de la "jurisprudencia menor" cabe destacar la SAP Tarragona de 3 de febrero de 2000 [ $A C, 2000,853]$, que en un supuesto de ruptura de la convivencia de más de veinte años por fallecimiento, el tribunal afirma la inexistencia de cualquier derecho sucesorio intestado en la herencia del fallecido porque "la relación de convivencia no es generadora de derecho sucesorio alguno" y tampoco considera legitimada la pretensión por enriquecimiento injusto, por no cumplir los requisitos necesarios, al no constatarse el perjuicio directo y evaluable de la conviviente supérstite (fundamento jurídico $1^{\circ}$ ).

${ }^{77}$ En la presente sentencia una mujer casada, cuyo marido había desaparecido durante la Guerra Civil Española, inicia una convivencia estable, porque no puede contraer matrimonio so pena de incurrir en delito de bigamia. La unión extramatrimonial se mantuvo de forma pública, estable e ininterrumpida durante cincuenta y tres años, hasta la extinción de la misma por el fallecimiento del conviviente, el cual muere intestado, siendo llamada a la sucesión de su importante patrimonio su hermana. De nuevo, la conviviente no solicita al tribunal el reconocimiento de derechos sucesorios intestados, sino que reclama, en primer lugar, una indemnización de daños y perjuicios por la totalidad del haber hereditario por los años de convivencia con el causante; en segundo lugar, alternativa y subsidiariamente, que se le satisfaga, en concepto de pensión compensatoria por aplicación analógica del artículo 97 del $C C$, una cantidad suficiente para permitirle el mismo nivel de vida del que gozaba con el causante, así como la adjudicación en propiedad de la vivienda que sirvió de domicilio conyugal durante los años de convivencia; o en defecto de todo lo anterior, que se aplique la doctrina del enriquecimiento injusto para que se le compense el empobrecimiento sufrido. Véase Susana EsPADA MALLORQUín, "Enriquecimiento injusto y protección jurídica del conviviente supérstite. Comentario a la STS de 17 de junio de 2003”, en Revista de Derecho Patrimonial, No 12, Navarra, Aranzadi, 2004, pp. 335-345 y Marta Pérez Escolar, "Derechos sucesorios del conviviente supérstite. A propósito de la Sentencia del Tribunal Supremo de 17 de junio de 2003", en Revista Actualidad Civil, vol. I, Madrid, 2004, pp. 740-748. 
considera que, a pesar de la solicitud de la actora, no es posible ejercitar en este caso la acción de responsabilidad civil por culpa extracontractual o aquiliana (art. 1902 del $C C)^{78}$, ni tampoco entiende aplicable analógicamente la pensión compensatoria del artículo 97 del $C C$, por no estar ésta prevista para los supuestos de ruptura por fallecimiento ${ }^{79}$.

No obstante, la sentencia afirma que la solución pertinente es la restitución patrimonial por la aplicación de la doctrina del enriquecimiento injusto como mecanismo corrector de las desigualdades económicas derivadas de la convivencia de hecho. El empobrecimiento injustificado se correspondería con "la pérdida de expectativas y el abandono de la actividad en beneficio propio por la dedicación en beneficio de otro" (fundamento jurídico $\left.3^{\circ}\right)$. En este caso, la dedicación en exclusiva a la atención del causante y del hogar familiar, prestándole total ayuda moral y material, repercute positiva y significativamente en la formación del patrimonio de éste, al tiempo que para el conviviente supérstite implica un desentendimiento de su propio patrimonio, pues tal dedicación, ni está retribuida, ni goza de ninguna compensación económica, impidiéndole, además, obtener beneficios privativos por el desarrollo de otra actividad en provecho propio. Esto justifica la existencia de una correlación entre el enriquecimiento y el empobrecimiento en tanto cada uno determina el otro: mientras uno se beneficia del ahorro, el otro experimenta un lucro cesante. Mediante esta argumentación se entienden cumplidos los requisitos relativos al enriquecimiento y al correlativo empobrecimiento en estas situaciones de hecho. Además, el tribunal afirma que la convivencia en una comunidad de vida o el hecho de gozar de una determinada consideración social y material, no justifican por sí mismas el desequilibrio patrimonial que pudiera surgir entre las partes en el desarrollo de sus respectivas actividades, es decir, la mera existencia de una convivencia more uxorio no es causa de atribución patrimonial $^{80}$.

${ }^{78}$ Sobre esta materia, Alma María Rodríguez Guitian, "Función de la responsabilidad civil en determinadas relaciones de convivencia: daños entre cónyuges y daños entre miembros de la pareja de hecho", en Revista de Derecho Patrimonial, No 10, Navarra, 2003, p. 80 y ss.

${ }^{79}$ Véase María Dolores Cervilla Garzón, "Pensión compensatoria y uniones de hecho en la jurisprudencia del Tribunal Supremo", en Revista de Derecho Patrimonial, N $^{\circ} 10$, Navarra, 2003, pp. 583-585.

${ }^{80}$ Véase dentro de la jurisprudencia favorable al otorgamiento de una compensación a través de la doctrina del enriquecimiento injusto por la dedicación exclusiva al hogar familiar de uno de los convivientes, entre otras, STS de 27 de marzo de 2001 [RJ, 2001, 4770]; STS de 6 de octubre de 2006 [RJ, 2006, 6650]; SAP Asturias de 14 de marzo de 2000 [ $A C, 2000,1147]$; SAP Asturias de 28 de marzo de 2001 [AC, 2001, 1132]; SAP Barcelona de 28 de noviembre de 2001 [ $A C, 2001,543$ ]; SAP Lleida de 18 de enero de 2005 [ $A C, 2005$, 190]; SAP Murcia de 7 de febrero de 2006 [JUR, 2006, 141698] y SAP Pontevedra de 14 
Por esta vía y, dejando a un lado la consideración de cualquier derecho sucesorio intestado, el Tribunal Supremo decide a la hora de determinar los efectos del enriquecimiento atribuirle a la conviviente supérstite, sin mayor justificación, la cuarta parte de los bienes generados durante la convivencia, con exclusión de los heredados por el causante de su familia, en reparación de un enriquecimiento experimentado por el fallecido gracias a la dedicación exclusiva que la compañera supérstite le dispensó a él y al hogar familiar.

Posteriormente, en la STS de 23 de noviembre de $2004^{81}$, tras el fallecimiento de su pareja de hecho en accidente de tráfico, la conviviente supérstite promueve demanda contra los herederos del causante (los hijos de su primer matrimonio) sobre división de la cosa común, solicitando que se declare la existencia de una comunidad de bienes entre ella y el fallecido $\mathrm{y}$, subsidiariamente, en virtud de la acción de enriquecimiento injusto, se la compense por el empobrecimiento sufrido en cuantía equivalente a la mitad de los bienes constante su relación de hecho. En primera instancia y en apelación se desestima la demanda.

Sin embargo, el Tribunal Supremo declara ha lugar al recurso interpuesto y considera que a la actora le corresponde, en virtud de lo que denomina "el principio de protección del conviviente perjudicado por la 36 ruptura", un tercio del valor de los bienes dejados al fallecimiento por el causante, en la forma que lo ha determinado ${ }^{82}$. En este caso, hace una ex-

de septiembre de 2006 [JUR, 2006, 258143]. En el ámbito doctrinal, entre otros, EsTRADA Alonso (n. 47), pp. 225-227 y Álvarez Lata (n. 48), pp. 50-51.

${ }^{81}$ Según los hechos probados de la sentencia existe una convivencia de diecisiete años de duración hasta el fallecimiento de uno de sus miembros. El causante tenía tres hijos de un matrimonio anterior. Constante el matrimonio, el fallecido explotaba un negocio en un taller mecánico que le fue expropiado en 1975. En 1972, estando casado, adquiere por contrato privado una finca compuesta por una vivienda y un local donde instala su nuevo taller, firmando la escritura pública en 1976. Al poco tiempo de haber firmado la escritura de capitulaciones matrimoniales, se liquida y disuelve su sociedad matrimonial de gananciales, por la que se adjudica a la esposa en régimen de alquiler la vivienda familiar; y tras liquidación de la sociedad de gananciales, el fallecido también liquida el pago del precio aplazado de la finca. Por su parte, la conviviente supérstite estudia enfermería mientras convive con el causante y éste le costea los gastos de sus estudios. En el transcurso de la convivencia, el fallecido adquiere una casa en Riaza y tres naves industriales y, posteriormente, adquiere y vende otra serie de inmuebles. Por la sentencia de separación matrimonial se le impone el pago de una pensión alimenticia a favor de sus hijos y, en 1982, tras una gran litigiosidad entre los cónyuges, la ex mujer solicita la modificación de tales pensiones, coincidiendo esta solicitud con la titularidad a favor de la conviviente de algunas cuentas corrientes en las que se efectúan cargos y pagos del taller. Estas cuentas fueron embargadas para el pago de las pensiones.

${ }^{82}$ Este llamado principio general de protección del conviviente perjudicado por la relación de hecho fue enunciado por primera vez en la STS de 10 de marzo de 1998 [RJ, 
presa remisión a la doctrina de la protección del cohabitante perjudicado por la relación, pero no lo emplea para reconocer por esta vía los derechos sucesorios intestados que le correspondan, sino para reparar el perjuicio derivado de la relación, ya que de nuevo el tribunal se abstiene de realizar cualquier tipo de consideración de carácter sucesorio. En estos supuestos, se considera que 'perjuicio' es sinónimo de enriquecimiento injustificado de una de las partes $y$, al igual que en las sentencias anteriores, lo esencial para conceder esta protección a través de este principio es demostrar el concreto perjuicio sufrido y su injusticia. A mi juicio, esto permite afirmar que la aplicación del llamado principio de protección del conviviente más perjudicado por la ruptura, no difiere de la aplicación a la pareja supérstite de la doctrina del enriquecimiento injusto ${ }^{83}$.

Considero que, tal y como el Tribunal Supremo interpreta el llamado principio de protección del conviviente perjudicado, no se trata de una solución alternativa a la aplicación de la doctrina del enriquecimiento injusto a las parejas de hecho, sino que el llamado principio de protección no es más que una concreción del propio principio general de enriquecimiento injusto. Mediante el llamado "principio" sólo se hace una referencia a la ausencia de causa que impide considerar como justificados los desequilibrios patrimoniales que surgen de la convivencia de hecho y que legitima la restitución patrimonial tendente a eliminar un beneficio injustamente obtenido $^{84}$. Así, el tribunal considera que:

1998, 1272] y, posteriormente, fue consolidado por la STS de 17 de enero de 2003[RJ, 2003, 4]. Véase Manuel Pulido Quecedo, "El principio de protección al conviviente perjudicado por la situación de hecho: ¿un nuevo principio general del derecho?”, en Revista Actualidad Jurídica Aranzadi, No 586, Navarra, 6 de marzo de 2003, pp. 6-7.

${ }^{83}$ Véase, en este sentido, Santiago SALAZAR Bort, "Comentario a la STS de 17 de enero de 2003. De nuevo sobre parejas no casadas", en Revista Actualidad Jurídica, año XI, N 513, Navarra, Aranzadi, 2001, p. 3.

${ }^{84}$ He de destacar la SJPI Córdoba de 17 de octubre de 2003 [UUR, 2003, 244796] y la SJPI Cantabria de 7 de febrero de 2005 [AC, 2005, 331]. En la primera de ellas, tras una convivencias de más de cincuenta y siete años de duración y, ante la necesidad de compensar económicamente al conviviente en peor situación económica, por aplicación de la doctrina del enriquecimiento injusto y atendiendo a la extensa duración de la convivencia y a la denegación a la actora de la pensión de viudedad, se concede un tercio de los bienes que integran la herencia del conviviente fallecido, descontadas, previamente las deudas. La segunda sentencia citada, también considera legítima la pretensión de restitución del enriquecimiento injustificado, pero esta vez, en virtud de la aplicación del principio de protección de conviviente más perjudicado por la situación de hecho, simplemente constata la ausencia de una causa que justifique el enriquecimiento por las prestaciones realizadas. En este caso, se trata de una convivencia de cuatro años de duración, donde consta la dedicación de la conviviente supérstite al cuidado personal, lo que evita la necesidad de contratar una asistencia permanente por parte de terceros. 
"la compensación a conceder, no puede ser la de la mitad de los bienes del varón, pedida, puesto que no se acepta la tesis de la existencia de la comunidad de bienes, en sí o asimilada a la de gananciales, sino en el tercio de los bienes existentes a nombre del mismo al finalizar la unión por su óbito, y que figuran descritos en la sentencia de la Audiencia" (fundamento jurídico $\left.4^{\mathrm{O}}\right)^{85}$.

En resumen, el Tribunal Supremo para solucionar las consecuencias económicas negativas que sufre el conviviente supérstite tras el fallecimiento de su pareja estable y, ante la ausencia entre los convivientes de una comunidad de bienes o una sociedad irregular de ganancias, ha acudido a la doctrina del enriquecimiento injusto. A su vez, la existencia de acciones de enriquecimiento injusto tipificadas en distintas leyes autonómicas, ha sido utilizada por este tribunal como argumento a favor de una acción general de enriquecimiento injustificado aplicable a la situación derivada de la extinción de la unión extramatrimonial en el ámbito estatal ${ }^{86}$.

\section{c) Reflexión crítica sobre dicha jurisprudencia}

A pesar del rechazo que manifiesta el Tribunal Supremo en ambas sentencias a la utilización del argumento analógico, es imprescindible recordar que tanto el enriquecimiento injusto como la protección del conviviente

${ }^{85}$ Una vez más, el Tribunal Supremo no manifiesta de forma clara cuáles son los criterios que le llevan a cuantificar la restitución en un supuesto de enriquecimiento injusto concedida a favor de un conviviente. En este caso, resulta significativo que la cuantía (un tercio) sea idéntica a la que le corresponde al cónyuge viudo en Derecho Civil común, eso sí, con la importantísima salvedad de que la sentencia al conviviente supérstite le atribuye la cuota en propiedad, mientras que al cónyuge viudo se la otorga en usufructo. Algunos autores han señalado como criterios que pueden emplearse para cuantificar el ahorro en gastos que implica la dedicación en exclusiva de uno de los miembros al hogar familiar, entre otros elementos: el sueldo que cobraría un tercero por llevar a cabo las distintas actividades en el hogar familiar (empleado en el hogar, persona encargada del cuidado de los niños...); también el aumento de sus ingresos de patrimonio o de aptitudes profesionales; el empobrecimiento que supone la ausencia de retribución de esta dedicación al hogar y el costo de la formación necesaria para la incorporación o reincorporación al mercado laboral, etc. Sin embargo, como se acaba de mencionar, estos criterios para cuantificar la compensación no aparecen en ninguna de las sentencias mencionadas. Véase, entre otros, Gallego Domínguez (n. 47), p. 221.

${ }^{86}$ Son varias las comunidades autónomas que contemplan acciones tipificadas de enriquecimiento con las que se pretende evitar que se consoliden desplazamientos patrimoniales injustificados, aunque en todas ellas, salvo en el caso de la ley vasca, este reconocimiento sólo se realiza cuando la disolución de la relación es por causa distinta a la muerte o a la declaración de fallecimiento. Se contempla esta acción en los arts. 13 y 31.2 de la ley catalana; art. 7 de la ley aragonesa; art. 5.5 de la ley navarra; art. 9.2 de la ley balear; art. 7 de la ley extremeña; art. 6.2.b) de la ley vasca y art. 9 de la ley cántabra. 
perjudicado por la ruptura, son ejemplos de argumentación jurídica por analogía. Se trata de principios que se obtienen mediante inducción a partir de un conjunto normativo determinado y que se emplean para colmar una laguna normativa (analogía iuris) ${ }^{87}$. Esto difiere de la analogía legis, donde se aplica una norma legal particular a un hecho no regulado por ella, pero que mantiene con el caso regulado una identidad de razón ${ }^{88}$.

Esta distinción no resulta irrelevante. La analogía legis es el único proceso analógico de aplicación de las normas jurídicas que se contempla en el artículo 4.1 del $C C$. El recurso a la analogía iuris procederá cuando resulten de aplicación los principios generales del Derecho, aunque, en este caso, se trataría de principios generales de Derecho Positivo ${ }^{89}$. Según el sistema de prelación de fuentes del Código Civil español (art. 1 del CC), la aplicación del argumento jurídico por analogía legis es preferente a la analogía iuris $^{90}$, aunque el carácter de fuente del Derecho no es predicable en sentido estricto, ni de una ni de otra. No obstante, una vez que el juez verifique que se cumplen todos los requisitos exigibles para el uso de dicho argumento jurídico, su aplicación ha de ser automática ${ }^{91}$.

Por este motivo, afirmo que es preciso analizar los presupuestos necesarios para proceder a la aplicación de la analogía legis de los derechos sucesorios del cónyuge viudo al conviviente supérstite, porque de ser ésta

${ }^{87}$ Manuel Salguero realiza una distinción entre ambos principios, pues considera que dentro de la analogía iuris pueden distinguirse, a su vez, dos grados de generalización. El primero, deriva de la inferencia inductiva del principio general a partir de un determinado y finito número de normas. A este grado pertenecería el principio de enriquecimiento injusto (derivado, entre otros, de los arts. 356, 361, 453 y 505 del CC). El otro grado de generalización deriva de la inferencia inductiva realizada a partir de todo el ordenamiento, grado en el que se ubicaría el principio de protección del conviviente perjudicado por la ruptura [derivado de normas constitucionales (arts. 10 y 14 de la CE), de normas de Derecho Privado (art. 97 del $C C$ y art. 16 de la LAU)], véase Manuel Salguero Salguero, Argumentación jurídica por analogía, Madrid-Barcelona, Marcial Pons, 2002, pp. 168-171.

${ }^{88} \mathrm{La}$ analogía legis es procedimiento argumentativo que permite trasladar la solución prevista para un caso a otro distinto, no regulado, pero que se asemeja al regulado por compartir ciertas características esenciales. Véase Karl LAREnz, Metodología de la Ciencia del Derecho, Barcelona, Ariel Derecho, 1994, p. 376.

${ }^{89}$ Manuel Salguero destaca la importancia de no confundir la analogía iuris con los principio generales de Derecho, puesto que: "los primeros se restringen a principios generales extraídos por inducción de un determinado conjunto normativo a los que puede denominarse principios generales de Derecho positivo", mientras que "los principios generales de Derecho pueden ser también principios extrapositivos o extrasistemáticos, de raíz iusnaturalista racionalista”, SAlguero SAlguero (n. 87), p. 178.

${ }^{90}$ Antonio Gullón Ballesteros, "Comentario al artículo 4 CC", en Comentarios al Código civil, Madrid, Ministerio de Justicia, 1993, pp. 29-30.

${ }_{91}$ María José Falcón y Tella, El argumento analógico en el Derecho, Madrid, Civitas, 1991, pp. 218-224. 
admisible, será la solución más ajustada al ordenamiento y deberá de aplicarse preferentemente a la analogía iuris. En mi opinión, es preferible que el legislador lleve a cabo una regulación expresa en esta materia, pero de lege lata será necesario determinar si es admisible el recurso a la analogía respecto de dichos derechos sucesorios del cónyuge viudo, al igual que ya se ha admitido en relación con otras disposiciones de carácter matrimonial $^{92}$.

\section{La aplicación analógica de los derechos sucesorios del cónyuge viudo al conviviente supérstite}

De acuerdo con lo expuesto previamente, en el sistema de fuentes del Código Civil español la regla general es que la analogía legis ha de aplicarse con preferencia a la analogía iuris. Esta regla es la que me permite plantear que, ante la ausencia de regulación estatal, antes que la aplicación de la analogía iuris, hay que estudiar si es posible aplicar de manera analógica al conviviente supérstite determinados derechos sucesorios del cónyuge viudo, pues ésta sería una solución más ajustada a Derecho.

Como es sabido, para que proceda la citada analogía legis se han de dar una serie de requisitos ${ }^{93}$. A continuación, se estudiará cada uno de ellos

${ }^{92}$ Véase las SSTS de 27 de marzo de 2001 [RJ, 2001, 4770] y la de 5 de julio de 2001 [RJ, 2001, 4993], donde se aplican analógicamente los artículos 96 y 97 del $C C$ a convivencias de más de quince años de duración que se disuelven por ruptura unilateral. Véase también los comentarios de María Carmen CRespo MorA, "Ruptura de la unión: aplicación analógica de las normas sobre crisis matrimonial. Comentario a la STS de 27 de marzo de 2001", en Revista de Derecho Patrimonial, No 9, Navarra, Aranzadi, 2002, pp. 513-524; Enrique Rubio Torrano, "Parejas estables y anomia en el Derecho", en Aranzadi Civil, vol, I, Navarra, 2001, pp. 1.827-1.829 y Santiago SAlazAr Bort, "Comentario a la STS de 27 de marzo de 2001. Uniones de hecho y compensación del trabajo doméstico", en Revista Actualidad Jurídica, año XI, No 513, Madrid, 20 de diciembre de 2001, pp. 2-7 y "Pareja de hecho y pensión compensatoria (Comentario a la STS de 5 de julio de 2001)", en Actualidad Civil, No 2, Madrid, 2002, pp. 751-758.

Es evidente que esta opción argumentativa implica cierta inseguridad jurídica, sin embargo, entiendo que ésta no es consecuencia de la aplicación de la argumentación por analogía legis, sino de la ausencia de una regulación sobre esta materia. Véase en idéntico sentido, Crespo Mora (n. 92), p. 520.

${ }^{93}$ Sobre los aspectos generales de la aplicación el argumento analógico véase, entre otros, Manuel Atienza Rodríguez, Sobre la analogía en el Derecho. Ensayo de análisis de un razonamiento jurídico, Madrid, Civitas, 1986, pp. 34-41; Luis DíEz-PicAzo, Experiencias jurídicas y teoría del Derecho, Barcelona, Ariel, 1973, pp. 283-284; Larenz (n. 88), p. 376; SAlguero Salguero (n. 87) p. 178; Susana SÁnchez Ferro, "Analogía e imperio de la ley”, en Anuario de Filosofía del Derecho, No 13-14, Madrid 1996, pp. 652-653 y Juan B. VAllet De Goytisolo, "La analogía en el Derecho", en Anuario de Derecho Civil, No 48, vol. III, Madrid, 1995, pp. 1.079-1.080. 
para ver la pertinencia o no de la aplicación del citado argumento analógico para proceder al reconocimiento de efectos sucesorios al conviviente supérstite por parte de los tribunales, hasta que la procedente reforma legislativa se produzca.

\section{a) La existencia de una laguna normativa}

El primero de los requisitos que legitima el empleo de la argumentación jurídica por analogía es la existencia de una laguna legal. Para poder afirmar su existencia es necesario determinar la voluntad del legislador e interpretar de forma adecuada su silencio normativo, pues puede que se trate de un vacío normativo voluntario. En ese caso, sólo podemos calificar la ley como criticable, ya que no necesita un mecanismo integrador interpretativo, sino una reforma legislativa efectiva del texto normativo que responda a esa crítica ${ }^{94}$.

En este proceso, destinado a valorar e interpretar el silencio normativo del legislador, es necesario tener en consideración la necesidad de una coherencia interna del propio ordenamiento y la constatación de las líneas de política normativa. Por un lado, existen argumentos que pueden hacer pensar que el legislador estatal en las sucesivas legislaturas ha querido evitar deliberadamente la regulación de la parejas de hecho ${ }^{95}$, dado el tiempo transcurrido en ausencia de regulación desde que se toma conciencia de esta realidad social, o el reiterado fracaso de las proposiciones presentadas para la aprobación de una ley estatal de parejas de hecho ${ }^{96}$. Por otro lado, los sucesivos legisladores no han ignorado a las parejas de hecho, ya que existen varias disposiciones estatales en las que éstas son tomadas en consideración de manera fragmentaria tanto para el reconocimiento efectivo de derechos como para el establecimiento de obligaciones, en materias tan relevantes como la adopción, los arrendamientos urbanos o, recientemente, el otorgamiento de la pensión de viudedad ${ }^{97}$.

${ }^{94}$ Manuel Segura Ortega, "El problema de las lagunas en el Derecho", en Anuario de Filosofía del Derecho, tomo vi, Madrid, 1989, pp. 303-307.

${ }^{95}$ Julio V. GaVidia SÁnchez, “¿Es la unión libre una situación análoga al matrimonio?”, en Revista Jurídica de Navarra, No 32, Navarra, octubre-diciembre 1999, p. 199 y Enrique BRANCós NúÑEz, "Derechos sucesorios de las uniones estables de pareja”, en Juan Francisco Delgado de Miguel, Instituciones de Derecho Privado, tomo v, vol. III, Madrid, ThomsonCivitas, 2005, p. 948.

${ }^{96}$ Dentro de la jurisprudencia encontramos sentencias que niegan rotundamente la existencia de esta laguna. En este sentido, STS de 30 de diciembre de 1994 [RJ, 1994, 10391] o STS de 4 de marzo de 1997 [RJ, 1997, 1649]. Otras afirman la existencia de dicha laguna. Es el caso de la STS de 18 de mayo de 1992 [RJ, 1992, 4907]; STS de 5 de julio de 2001 [RJ, 2004, 4993] o STS de 5 de febrero de 2004 [RJ, 2004, 213].

${ }^{97}$ Véase las referencias legislativas citadas en los apartados II. 1. a) y III. 1. del presente artículo. 
Junto a esta situación estatal, tal y como se ha puesto en evidencia, el peculiar reparto de competencias legislativas del ordenamiento español y la existencia de numerosas regulaciones autonómicas de parejas de hecho, muy diversas entre sí, también ha podido motivar una excesiva prudencia por parte del legislador estatal a la hora de decidirse a elaborar una norma estatal o de realizar modificaciones parciales en las disposiciones de Derecho Civil común. Esto se debe a que la aprobación de una normativa estatal traería consigo importantes consecuencias, pues haría más evidente el problema del conflicto de competencias legislativas sobre esta materia que, seguramente, derivaría en el correspondiente conflicto autonómico, provocando la necesaria derogación de alguna de las legislaciones vigentes.

En mi opinión, el silencio normativo del legislador estatal respecto del reconocimiento de efectos jurídicos sucesorios a las parejas de hecho no es un silencio legislativo elocuente o una omisión deliberada. La pareja de hecho no está regulada legalmente, pero tampoco está prohibida por el Derecho. No creo que el legislador, en virtud del respeto a la libertad de quien decide no contraer matrimonio, pretenda omitir de forma voluntaria el reconocimiento de esos efectos jurídicos a estas relaciones afectivas, es decir, negarle los derechos sucesorios ex lege al conviviente supérstite en la herencia de su pareja fallecida. De hecho, ya ha comenzado a atribuirles efectos post mortem en el ámbito de la seguridad social, al reconocer el derecho de esta pareja a la pensión de viudedad. Hasta la fecha, el plan del legislador estatal sobre el reconocimiento de efectos jurídicos a estas parejas está siendo fragmentario, pero también cada vez más progresivo, afectando a todos los ámbitos del ordenamiento. Por todo ello, interpreto que el actual silencio normativo estatal sobre el reconocimiento de derechos sucesorios al conviviente supérstite, implica la existencia de una laguna legal que ha de colmarse para otorgar la oportuna coherencia interna del propio ordenamiento con su última línea de política normativa.

Es cierto que el primero que está llamado a eliminar esta laguna es el legislador estatal, pero ante su pasividad y la evidente necesidad judicial de dar una respuesta adecuada a la realidad social de estas situaciones, creo que es legítimo que los jueces las colmen mediante el empleo del argumento analógico; eso sí, encontrando el oportuno equilibrio entre el respeto a los criterios de seguridad jurídica y de justicia. Además, no hay que olvidar que el significado de la proposición análoga integradora de la laguna no suprime la existencia de la misma en la ley, ya que sólo la colma temporalmente para un caso concreto, por lo que la laguna legal continuará y seguirá siendo necesaria la oportuna reforma legislativa que la subsane. Luego, si bien es cierto que el legislador estatal está llamado a colmar esa laguna, hasta que no lo haga, considero que los jueces, cuando resuelvan 
los casos concretos, pueden y deben aplicar la analogía si se cumplen los demás requisitos.

\section{b) La identidad de razón entre el supuesto regulado}

\section{y el carente de regulación}

El segundo requisito del argumento analógico es la identidad de razón entre el supuesto regulado y el que carece de regulación. Son numerosas las sentencias del Tribunal Supremo en las que se niega la pertinencia del reconocimiento de determinados efectos jurídicos típicamente matrimoniales a los convivientes de hecho mediante el recurso a la analogía, porque argumentan que matrimonio y convivencia de hecho son dos realidades diferentes.

Entre las diferencias que se mencionan en estas sentencias se destaca el carácter puramente fáctico de las parejas de hecho, la ausencia de todo vínculo formal entre los convivientes que permite la libre ruptura de la relación, o su percepción como una realidad social cada vez más consolidada, pero que da cabida a situaciones muy diversas entre si ${ }^{98}$. El Tribunal Supremo entiende que todos estos elementos ponen en evidencia que ambas situaciones -matrimonio y pareja de hecho- no son realidades equivalentes, lo que dificulta la certeza jurídica necesaria para poder reconocer a estas relaciones personales y patrimoniales de hecho alguno de los efectos típicos del matrimonio ${ }^{99}$.

La aceptación de esta premisa supone negar la identidad de razón entre el supuesto de hecho de las normas que regulan el estatuto legal del matrimonio y las parejas de hecho, incluidas las disposiciones que contemplan los derechos sucesorios del cónyuge viudo. Según este argumento, no existe una justificación razonable para que se reconozcan efectos jurídicos equivalentes al cónyuge viudo y al conviviente supérstite. Esta doctrina jurisprudencial afirma que la constatación de que las parejas de hecho constituyen un hecho social innegable, no supone que se le deban reconocer necesariamente los mismos efectos que a la institución matrimonial, empleando una interpretación de la regulación del matrimonio, según la realidad social del tiempo en el que ha de ser aplicada (art. 3 del $C C)^{100}$.

${ }^{98}$ Valpuesta Fernández (n. 28), p. 4.204.

${ }^{99}$ Véase, entre otras, SSTS de 21 de octubre de 1992 [RJ, 1992, 8589]; 18 de febrero y 22 de julio de 1993 [RJ, 1993, 1246 y 6274]; 27 de mayo de 1994 [RJ, 1994, 3753]; 24 de noviembre de 1994 [RJ, 1994, 8946]; 17 de enero de 2003 [RJ, 2003, 4] y la polémica STS de 12 de septiembre de 2005 [RJ, 2005, 7148]. En idéntico sentido, en la "jurisprudencia menor", hay que destacar SAP Burgos de 22 de febrero de 2006 [JUR, 2006, 133769] y SAP Madrid de 2 de febrero de 1999 [AC, 1999, @ 481].

${ }^{100}$ En este sentido, el fundamento jurídico único de la STS de 27 de mayo de 1994 [RJ, 1994, 3753]. Igualmente, véase Francisco VEGA SALA, "Las uniones de hecho en la 
Sin embargo, no toda la jurisprudencia se manifiesta en idéntico sentido. Existen varias sentencias donde el Tribunal Supremo ha aplicado por analógía determinadas disposiciones sobre efectos matrimoniales a las parejas de hecho, porque considera que entre ellas existe la semejanza necesaria. En estos casos, se entiende que tanto el matrimonio como la pareja de hecho son comunidades de vida donde existe una análoga relación de afectividad entre los miembros que las forman y que ambas realidades configuran situaciones familiares constitucionalmente protegidas ${ }^{101}$.

Por su parte, la doctrina se encuentra dividida en este punto. Existen autores que sostienen que el matrimonio y la pareja de hecho no pueden encuadrarse dentro de un plano de igualdad. Son situaciones diferentes, puesto que los miembros de la pareja de hecho optan por una relación afectiva donde el compromiso entre sus miembros se renueva de manera constante y cuya ruptura es esencialmente libre; mientras que los cónyuges, ante todo, buscan la estabilidad de la relación mediante el compromiso que adquieren por el vínculo matrimonial, del que se derivan unos especiales derechos y obligaciones y que conlleva el cumplimiento de ciertos requisitos para su disolución ${ }^{102}$. Por el contrario, otros autores afirman la existencia de una semejanza efectiva entre la comunidad de vida matrimonial y la convivencia more uxorio, porque ambas parten de la libertad para constituir 44 la relación y porque las relaciones familiares que de ambas situaciones se derivan son semejantes, pues tienen como objetivo el desarrollo de un

jurisprudencia del Tribunal Supremo", en Luis ZARRALUQUi y otros, Cuestiones derivadas de los pleitos de familia, Madrid, Dykinson, 1996, pp. 107-122.

${ }^{101}$ Véase, en este sentido, SSTS de 16 de diciembre de 1996 [RJ, 1996, 9020]; 29 de octubre de 1997 [RJ, 1997, 7341] y 5 de julio de 2001 [RJ, 2001, 1064]. De nuevo, hay que destacar la STS de 12 de septiembre de 2005 [RJ, 2005, 7148], en cuyo voto particular realizado por los magistrados Encarna Roca i Trías y Gabriel Ferrándiz, ambos se manifiestan a favor de la analogía en este caso.

102 Encabeza este rechazo Julio V. Gavidia Sánchez, "La unión libre: familia, no matrimonio", en La Ley, No 6038, Madrid, 1 de junio de 2004, D- 131, pp. 1.878-1.888; (n. 31), pp. 79, 126-127; (n. 95), pp. 206-254 y "Analogía entre el matrimonio y la unión de hecho en la jurisprudencia del Tribunal Supremo y el principio de libre ruptura de la unión no matrimonial", en Aranzadi Civil, No 1 Navarra, 2002, pp. 2.370-2.386. También niegan la identidad de razón: Brancós NúÑEZ (n. 95), pp. 963-967; Federico CANTERo NúÑEz, "Uniones de hecho", en Juan Francisco Delgado De Miguel, Instituciones de Derecho privado. Familia, tomo IV, vol. I, Madrid, Civitas, 2001, pp. 472-473; Martín Garrido MELERo, "El régimen jurídicos de las parejas de hecho", en VV.AA., El nuevo derecho de familia: modificaciones legislativas y tendencias doctrinales, Madrid, Thomson-Civitas, 2006, p. 156; Sergio Llebaría SAMPER, Hacia la familia no matrimonial, Barcelona, Ceders, 1997, pp. 147-148 y Pau SALVADOR Coderch, Marc R. Lloveras i Ferrer y Carles Seuba i Torreblanca, "Amor et caritas. La parella de fet en el Dret successori de Catalunya", en Àrea De Dret Civil (coord.), Setenes Jornades de Dret Català a Tossa. El nou Dret Successori de Catalunya, Barcelona, Universitat de Girona. PPU, 1994, p. 214. 
proyecto de vida en común ${ }^{103}$. Por estos motivos, se considera legítima la aplicación analógica de ciertas normas matrimoniales a las parejas de hecho, porque se cumple el requisito de la identidad de razón en estos casos.

En primer lugar, hay que precisar que la identidad de razón en la argumentación por analogía implica que entre el supuesto de hecho contemplado por la ley y el carente de regulación existe una semejanza, pero no una identidad ${ }^{104}$. La similitud entre los supuestos entraña en sí misma la diferencia que impide que sean idénticos y, por este motivo, toda aplicación de una norma jurídica por analogía supone cierto juicio de valor sobre la conveniencia de la aplicación ${ }^{105}$. Además, el argumento jurídico por analogía legis que planteo, como se verá en el siguiente apartado, toma como premisa del razonamiento sólo de una norma concreta, por lo que la cuestión a debatir no es si el matrimonio y la pareja de hecho son situaciones equivalentes en términos generales y absolutos, sino si en un determinado supuesto previsto en una norma matrimonial concreta concurren las razones de semejanza suficientes entre la convivencia de hecho y el matrimonio que permiten afirmar dicha identidad de razón.

En mi opinión, hay elementos suficientes que acreditan la semejanza entre el matrimonio y el concepto restringido de pareja de hecho a la hora de contemplar el reconocimiento de determinados derechos sucesorios; y hablo de la semejanza con el matrimonio entendiendo éste, no como institución, sino como convivencia more uxorio entre sus miembros. Es evidente que la pareja de hecho no es idéntica o equivalente a la institución matrimonial, pero sí es semejante respecto de la manera en la que se desarrolla la comunidad de vida y afectos entre los cónyuges y los convivientes. En ambas comunidades existe un proyecto de vida en común -que en un caso se asume mediante un compromiso jurídicamente vinculante y que, en el otro, se renueva a diario, mediante la convivencia efectiva-; ambas responden a intereses típicamente familiares; entre los miembros de las parejas existen cuidados y responsabilidades recíprocas, que en un caso derivan del vínculo matrimonial asumido y, en el otro, surgen de la propia convivencia more uxorio. Por todo ello, creo probado que el matrimonio y convivencia de hecho no son situaciones idénticas, pero sí que son análogas o semejantes.

Una vez que se cumple el requisito de semejanza del supuesto de hecho normativo, dentro del requisito de la identidad de razón habrá que deter-

${ }^{103}$ Véase Francisco Rivero Hernández, “Comentario a la STS 29 de octubre de 1997”, en Cuadernos Civitas de Jurisprudencia Civil, No 46, Madrid, 1998, p. 194 y Torres EsCÁmez (n. 62), p. 125.

${ }^{104}$ Encarna Roca I Trías, "Comentario al artículo 4 del Código civil”, en Comentarios al Código civil y Compilaciones forales, Madrid, Edersa, 1992, p. 604.

${ }^{105}$ Luis Díez-Picazo y Ponce de León y Antonio Gullón Ballesteros, Sistema de Derecho Civil, Madrid, Thomson-Civitas, 2006, pp. 180-183. 
minar cuál es el fundamento de las normas que pretendemos aplicar de manera analógica, porque será la ratio de cada norma la que en definitiva determine si, finalmente, procede o no la analogía. Es necesario precisar si el fundamento de la norma cuya aplicación analógica pretendemos llevar a cabo tiene en cuenta los elementos que asemejan ambas realidades (la convivencia more uxorio) o los que las diferencian (existencia de vínculo). En el caso que nos ocupa, hay que establecer si el fundamento del otorgamiento de las disposiciones que regulan determinados derechos sucesorios del cónyuge viudo se encuentra en la existencia de un vínculo matrimonial, o si, por el contrario, se encuentra en otro tipo de vínculos de carácter puramente afectivo y de desarrollo de la convivencia.

c) La identidad de razón respecto de la ratio legis de determinados preceptos sucesorios

Si aceptamos las anteriores premisas, la identidad de razón también ha de acreditarse en cada uno de los preceptos que reconocen derechos sucesorios al cónyuge viudo y que se pretenden aplicar por analogía al conviviente supérstite. Es decir, la conexión de la ratio legis de los preceptos sucesorios ha de ser relevante y ésta lo será cuando el caso no regulado coincida con el regulado en aquellos aspectos que se estimen determinantes, según el 46 fin de protección de la norma ${ }^{106}$.

\section{i. Los derechos sucesorios intestados}

Comenzando por los derechos sucesorios intestados, los preceptos que se verán afectados son los relativos al llamamiento y al orden del mismo en la sucesión (arts. 913, 943 y $954 \mathrm{del} C C$ ) y a la atribución efectiva de derechos intestados (arts. 944 y 945 del $C C$ ) ${ }^{107}$. Respecto de estos últimos, ya desde la reforma del Código Civil español de 1981 considero que el fundamento del reconocimiento de derechos sucesorios al cónyuge viudo en la sucesión intestada, no se encuentra en la existencia y cumplimiento de los deberes derivados del vínculo matrimonial, sino que reside en la existencia, vigencia y solidez de los vínculos afectivos que se deducen de la vida en común ${ }^{108}$.

${ }^{106}$ Sánchez Ferro (n. 93), p. 667.

${ }^{107}$ Véase Fernando Crespo Allué, "Comentario al nuevo artículo 945 CC”, en Vicente Guilarte Gutiérrez y otros, Comentarios a la reforma de la separación y el divorcio: Ley 15/2005, de 8 de julio, Valladolid, Editorial Lex Nova, 2005, p. 296.

${ }^{108}$ García Goyena, Florencio, Concordancias, motivos y comentarios del Código civil español, apéndice número 10, Madrid, Imprenta de la Sociedad Tipográfico-Editorial, 1852, vols. I-II, y Barcelona, Editorial Base, 1973, pp. 360-361 y Ignacio Gomá Lanzón, "Los derechos sucesorios del cónyuge viudo", en Juan Francisco Delgado de Miguel, Instituciones de Derecho Privado, tomo v, vol. III, Madrid, Thomson-Civitas, 2005, pp. 605-632. 
No se reconoce el derecho a suceder intestado por el mero hecho de ser el cónyuge del fallecido, sino por mantener un vínculo de convivencia íntima con el causante en el momento del fallecimiento ${ }^{109}$.

Esta idea sobre el fundamento de la sucesión intestada del cónyuge viudo se ha visto reforzada con la última reforma del artículo 945 del $C C$. Tras la reforma de la Ley 15/2005, de 8 de julio, basta la mera separación de hecho -con independencia de que conste fehacientemente o no-para que el cónyuge separado carezca de derechos en la sucesión intestada de su pareja. Esto permite sostener que lo esencial para el reconocimiento de derechos sucesorios intestados es la existencia entre el causante y su pareja de una convivencia more uxorio que justifique el llamamiento en ausencia de una disposición en contrario. Esta convivencia es la que se relaciona con la hipotética voluntad típica de un causante medio, por lo que creo que en la sucesión intestada la convivencia efectiva tiene un valor mayor que la propia vigencia del vínculo matrimonial a la hora de proceder al reconocimiento de estos derechos sucesorios ${ }^{110}$.

Si aceptamos las anteriores premisas, estimo oportuno afirmar que si se acredita que el causante tenía una pareja de hecho en sentido estricto, atendida la ratio legis de estas disposiciones, en ausencia de ascendientes y descendientes y, siempre que en el momento del fallecimiento la convivencia de hecho estuviera plenamente vigente, mediante la argumentación jurídica por analogía legis se podrá reconocer el derecho del conviviente supérstite a suceder abintestato a su pareja fallecida, de manera preferente a los colaterales y al propio Estado. En mi opinión, este reconocimiento ni debilita la institución familiar, ni lesiona la libertad y autonomía de los sujetos, sino que permite equiparar en efectos dos situaciones entre las que existe una identidad de razón suficiente.

Asimismo, si se admite la analogía entre el cónyuge viudo y la pareja supérstite en el supuesto contemplado en los artículos 944-945 del $C C$, implícitamente estamos admitiendo que el llamamiento y el orden sucesorio

${ }^{109}$ Esta opinión no es unánime. Autores como Gabriel García Cantero, "Sucesión intestada a favor de convivientes (Una resolución sorprendente de la Audiencia Provincial de Alicante)", en Revista Jurídica del Notariado, No 43, Madrid, julio-septiembre 2002, p. 330; José M. GonzÁlez PorRas, "La familia sin matrimonio (Notas a propósito de dos Proyectos de ley italianos sobre la familia de hecho)", en Revista Actualidad Civil, No 31, Madrid, 1990, p. 457 o Llevaría SAmper (n. 102), p. 148; consideran que el fundamento de la sucesión intestada está en la existencia de unos vínculos de parentesco o matrimoniales.

${ }^{110}$ Véase Carmen de Amunátegui Rodríguez, Uniones de hecho. Una nueva visión después de la publicación de las Leyes sobre parejas estables, Valencia, Tirant, Monografías No 221, 2002, pp. 274-276; Martín Pérez (n. 62), p. 1.097; Reina y Martinell (n. 9), pp. 78-79), Rivero Hernández (n. 103), pp. 198-199 y Agustín Romero Pareja, "Los derechos sucesorios de las uniones familiares no matrimoniales", en La Ley, año XxIV, N $^{\circ}$ 5757, Madrid, 9 de abril de 2003, p. 3. 
del sobreviviente supérstite -por idénticas razones analógicas- ha de ser el mismo que le corresponda al cónyuge viudo en la sucesión intestada ${ }^{111}$. Esto supone interpretar que tanto en el artículo 913 del $C C$-donde se contiene la delación legal en estos casos-, como en los artículos 943 y 954 del $\mathrm{CC}$-donde se hace referencia al orden sucesorio-, la mención referida al cónyuge viudo también es aplicable por vía analógica en favor del compañero supérstite. Dado que la existencia y solidez de los vínculos afectivos que se derivan de la convivencia more uxorio efectiva es lo que justifica su llamamiento preferente a los parientes colaterales y, precisamente, estos vínculos afectivos también surgen entre los convivientes, considero que está plenamente justificado el recurso a la analogía legis respecto de los mencionados derechos sucesorios intestados.

\section{ii. Los derechos legitimarios y la reserva viudal}

Por lo que se refiere a la ratio legis de los derechos legitimarios del cónyuge viudo (arts. 807 y 834 del $C C$ ), ésta es más compleja, sobre todo porque, históricamente, la legítima del cónyuge viudo ha experimentado una evolución oscilante en el ordenamiento jurídico español ${ }^{112}$.

Antes de la citada ley de 2005, en virtud de la interpretación del artículo 834 del $C C$ llevada a cabo por un amplio sector doctrinal, no se privaba de la legítima al cónyuge no culpable de la separación, por lo que podía sostenerse que lo esencial para la atribución de los derechos legitimarios era la vigencia del vínculo institucional del matrimonio ${ }^{113}$. Si la ratio legis del

${ }^{111}$ Pantaleón Prieto, A. Fernando, “¿Derechos sucesorios abintestato del compañero o compañera en la Compilación de Derecho civil de Cataluña?”, en Bartolomé Clavero, La reforma de la Compilación: el sistema successori. Materials IIIJornades de Dret Català a Tossa, mar, 26-29 de septiembre de 1984, Barcelona, Universitat de Barcelona, Càtedra de Dret Civil Català "Duran i Bas", 1984, p. 175 y (n. 46), p. 74.

${ }^{112}$ Véase María Mercedes Bermejo Pumar, "Atribuciones legales: la legítima”, en Juan Francisco Delgado De Miguel, Instituciones de Derecho Privado, tomo v, vol. III, Madrid, Thomson, 2005, pp. 44-102; Celestino CANo Tello, "El artículo 834 del Código civil desde la perspectiva de los derechos históricos y de los principios del Derecho de familia español", en Centenario del Código civil, Madrid, Centro de Estudios Ramón Areces, 1990, vol. I, pp. 393-404; José E. Maside Miranda, Legítima del cónyuge supérstite, Madrid, Centro de Estudios Hipotecarios, 1989 y Juan B. VAllet de Goytisolo, "Panorama de las legítimas y de su diversa naturaleza", en Libro-Homenaje a Lorenzo Herrera Mendoza, Caracas, Universidad Central de Venezuela, 1970, tomo I, pp. 575-595.

113 Antes de la reciente reforma de 2005, existía una polémica doctrinal sobre la interpretación integradora del contenido de los artículos 834 y 945 del $C C$. El cónyuge viudo no era llamado a la sucesión intestada a la totalidad de la herencia cuando existía una separación judicialmente decretada, o si se acreditaba una separación de hecho con el mutuo acuerdo de no continuar conviviendo en pareja. Sin embargo, los derechos legitimarios persistían para el no culpable en los casos de separación de hecho y de separación judicial. Esto se debía al distinto fundamento de la sucesión intestada y de la legítima, puesto que la 
reconocimiento de los derechos legitimarios del cónyuge viudo se encontraba en la existencia del vínculo matrimonial, puesto que los convivientes de hecho no establecen un vínculo matrimonial con su pareja, no procedía dicho reconocimiento de derechos legitimarios por vía analógica, porque el conviviente supérstite en ningún momento había adquirido con el causante el compromiso jurídico-matrimonial necesario para su atribución.

Tras la reforma de 2005, que suprime la causalidad en la separación y en el divorcio y que reforma el mencionado artículo 834 del $C C$-privando de la legítima al cónyuge separado de hecho-, parece que, ahora, lo esencial para reconocer derechos legitimarios al cónyuge viudo es la acreditación de la vigencia efectiva de la convivencia more uxorio entre los cónyuges en el momento del fallecimiento y no la existencia del vínculo institucional del matrimonio. El fundamento de la legítima del cónyuge viudo no se encuentra en el matrimonio como institución, sino en el matrimonio como comunidad de vida y afectos, en la existencia de una affectio maritalis que hace referencia a la vinculación afectiva entre unos sujetos, comunidad de vida que se caracteriza por la ayuda, el respeto y el socorro mutuo que constituye la base de su convivencia. Por ello, en la actualidad, entiendo que la identidad de razón para la aplicación analógica de estas normas queda acreditada.

Es cierto que, tras esta reforma del Código Civil español, el fundamento de los derechos abintestato y el de los derechos legitimarios del cónyuge viudo se han aproximado, pero sigue existiendo una diferencia esencial que no se debe perder de vista. Los derechos sucesorios intestados sólo se reconocen en ausencia de una disposición expresa del causante; mientras que los derechos legitimarios han de reconocerse aun en contra de la voluntad expresa del causante. Esta diferencia justifica los distintos efectos que la ley otorga a una y otra institución sucesoria; y, precisamente, el distinto carácter normativo de estas disposiciones sucesorias es lo que hace que sea necesario dar un paso más a la hora de afirmar la oportunidad del empleo del argumento analógico en uno y otro caso. Es decir, tras la reforma de 2005, el problema jurídico del reconocimiento de estos derechos sucesorios ex lege no es una cuestión de su fundamento normativo, sino que lo

primera se basaba en la voluntad hipotética de un testador medio, mientras que la segunda es derecho imperativo y se justificaba su mantenimiento en el caso de los separados por causa imputable al cónyuge premuerto, por consideraciones puramente familiares. Véase el análisis sobre dicha polémica doctrinal realizado por Manuel EsPejo LERdo DE TeJADA, La legítima en la sucesión intestada en el Código civil, Madrid, Marcial Pons, 1996, p. 129 y José María Miquel GonzÁlez, "Comentario a los artículos 761-814 CC”, en Manuel Amorós Guardiola, Comentarios a las Reformas de Derecho de Familia, Madrid, Tecnos, 1984, vol. II, pp. 1.275-1.303. La actual redacción ha armonizado los artículos 834 y 945 del $C C$, ya que al no existir causas de separación, ya no es posible hablar de cónyuges culpables de la misma. 
imprescindible para que sea posible la analogía en materia de derechos legitimarios es determinar si se cumple el último requisito del fundamento analógico, es decir, que no exista una disposición legal que impida acudir a esta argumentación en este caso (art. $4.2 \mathrm{del} C C$ ), requisito que se analizará más adelante.

En cuanto a la reserva viudal (arts. 968 a 980 del CC), la ratio legis del artículo 968 del $C C$ es proteger los intereses de los hijos de sus relaciones afectivas anteriores, en el momento de iniciar una nueva relación ${ }^{114}$. Dejando a un lado la polémica existente en el ordenamiento español sobre la oportunidad de la vigencia de la reserva viudal ${ }^{115} \mathrm{y}$, a pesar de que el tenor literal del mencionado artículo no contempla en forma expresa las parejas de hecho, entiendo que, dada la ratio de la norma, el único fundamento admisible de la reserva viudal es proteger a los hijos y descendientes del causante, con independencia de cual fuera el estado civil del causante al fallecer ${ }^{116}$. Es cierto que, al existir una amplia autonomía de la voluntad del causante, no es tan evidente que la reserva tenga que regularse como una obligación sucesoria forzosa; pero, en cualquier caso, a pesar de la crítica a la institución, su fundamento es la protección de los hijos y no, exclusivamente, de la familia matrimonial ${ }^{117}$. Por este motivo, para que

${ }^{114}$ Según el citado artículo, los únicos beneficiarios de la reserva viudal son los hijos matrimoniales, cuyo padre o madre viudo contrae un nuevo vínculo matrimonial tras el fallecimiento de su consorte. Véase Emilio GonzÁLEz Bou, "Reservas hereditarias”, en Juan Francisco Delgado De Miguel, Instituciones de Derecho Privado, tomo v, vol. III, Madrid, Thomson-Civitas, 2005, pp. 1.034-1.035 y Juan B. Vallet de Goytisolo, "Comentario al artículo 968 CC”, en Comentarios al Código Civil, Madrid, Ministerio de Justicia, 1993, tomo I, pp. 2.302-2.303.

115 Véase María Rosario Díaz Romero, "La reserva viudal. Vigencia actual”, en Anuario de Derecho Civil, tomo LIX, fascículo III, Madrid, julio-septiembre 2006, pp. 1.1991.242 .

${ }^{116}$ En el mismo sentido, José M. Bustos Lago, "Comentario al artículo 968 CC", en Rodrigo Bercovitz Rodríguez-Cano, Natalia Alvárez lata, Comentarios al Código Civil, Navarra, Aranzadi, 2001, p. 117; Gavidia SÁnchez (n. 26), pp. 89-90; GonZÁlez Bou (n. 114), pp. 1.036-1.037 y Martín Pérez (n. 62), p. 340.

${ }^{117} \mathrm{El}$ motivo por el cual se impone esta reserva al cónyuge viudo es evitar que cuando éste rehaga su vida afectiva, formando una nueva familia, disponga de determinados bienes que obtuvo de su primera pareja, en favor de su nueva pareja o de parientes de ésta, en lugar de a favor de los descendientes del causante. La existencia de una nueva relación afectiva del viudo es el motivo del que deriva la desconfianza del legislador y lo que justifica la imposición de la reserva sobre determinados bienes del causante, como medida protectora de los hijos de una primera relación. Considero que no existe una razón objetiva que justifique por qué los hijos matrimoniales han de desconfiar más del hecho de que se disponga de los bienes reservables cuando sus progenitores se casen de nuevo, que cuando se unan de hecho con un tercero. Además, esto favorece un posible fraude de ley, porque para evitar la obligación que impone la reserva viudal, bastará con que el viudo no contraiga un nuevo vínculo matrimonial, sino que establezca una convivencia more uxorio con un tercero para 
no se produzca una discriminación injustificada por razón de la filiación, considero que la obligación de reservar le corresponde, en todo caso, a los progenitores, casados o unidos de hecho, cuando tras el fallecimiento de su pareja, se casen de nuevo o convivan more uxorio mediante la aplicación analógica del citado precepto.

\section{iii. La sucesión testada}

Finalmente, respecto de la sucesión testada, un análisis pormenorizado de la ratio legis de diversas disposiciones permite verificar la identidad de razón respecto del fin perseguido por ciertas normas que tienen en cuenta la particularidad del sujeto como cónyuge/pareja del causante para producir determinados efectos. Podemos mencionar alguna de ellas:

- En las disposiciones relativas a la capacidad para suceder

Dentro de las incapacidades por la influencia, positiva o negativa, que se puede ejercer sobre el testador se encuentra la previsión de los artículos 753 y 754 del $C C$. En el primero de ellos se establece que las disposiciones del testador a favor del tutor o curador no surtirán efectos hasta que no se hayan aprobado las cuentas, o hasta que no se produzca la extinción de la tutela o curatela; sin embargo, estas disposiciones sí que se considerarán válidas cuando el tutor o curador es el cónyuge del testador. En el segundo artículo mencionado, se prohíbe al testador disponer del todo o de parte de su herencia en favor del cónyuge del notario que autorice el testamento ${ }^{118}$. En mi opinión, estas disposiciones son aplicables por analogía legis al conviviente. Tanto el cónyuge como la pareja more uxorio mantienen una especial relación de afectividad, derivada de la comunidad de vida y afectos que se desarrolla entre el causante y el tutor o curador y, entre el notario otorgante y su pareja y que, a su vez, legitima tanto el temor a que su voluntad sea captada como que la disposición en su favor esté basada en la confianza mutua que existe entre los miembros de la pareja. Por ello,

poder disponer libremente de los bienes reservables. Véase CANTERo NúÑEz (n. 102), pp. 477-478) y GonZÁLEZ Bou (n. 114), p. 1057.

${ }^{118}$ Estas incapacidades relativas tienen distinto fundamento. En el caso de las personas que intervienen en la formalización del testamento, el legislador teme que la voluntad del testador se encuentre viciada por la influencia que éstas pueden ejercer para captar su voluntad, es decir, la posibilidad de que se lleve a cabo una conducta engañosa en esas circunstancias, por la que se desvíe la voluntad del testador y éste cambie su testamento en un sentido distinto del originario. Por el contrario, en el caso de la tutela y curatela, el legislador, por esa proximidad en la relación con el causante, entiende que se justifica la ausencia de ese temor y legítima la validez de las disposiciones testamentarias a favor del tutor o curador. 
sostengo la validez de las disposiciones testamentarias que el causante realice en favor de pareja de hecho en los supuestos en los que éste sea su tutor o curador; y, del mismo modo, creo que no podrá el testador disponer de todo o de parte de su herencia en favor de la pareja de hecho del notario autorizante del testamento, porque es legítimo presuponer que, en esos casos, existe un riesgo claro de captación de su voluntad.

\section{- En las disposiciones relativas a la indignidad}

Por lo que se refiere a la posible indignidad del conviviente para suceder, en el artículo 756 del $C C$ se contemplan causas de indignidad específicas del cónyuge. Éstas operan tanto en la sucesión testada como en la intestada, aunque no son imperativas, porque el Código Civil español admite el perdón expreso o tácito de las mismas. Según el apartado segundo del citado artículo se considera incapaz de suceder por causa de indignidad al sujeto que "fuere condenado en juicio por haber atentado contra la vida del testador, de su cónyuge, descendiente o ascendiente. Si el ofensor fuere heredero forzoso, perderá su derecho a la legítima". En estos casos, el fundamento de la causa de indignidad es evitar que quien ha sido capaz de atentar contra la vida del causante o de las personas más allegadas a él, pueda llegar a convertirse en su heredero. Es posible interpretar la norma de manera restrictiva y literal, entendiendo que el término 'cónyuge' impide aplicar esta disposición analógicamente al compañero de hecho ${ }^{119}$.

Sin embargo, creo que esto no ha de ser así porque, a pesar de la interpretación restrictiva del término, el motivo por el cual se contempla al cónyuge en el mencionado artículo es la especial relación de afectividad y la comunidad de vida que le une al causante, pero no el hecho de que exista un vínculo formal con el testador. La reprochabilidad del acto de atentar contra el cónyuge, que justifica la indignidad, no se deriva del hecho de que se rompa el vínculo formal que el testador mantiene con el cónyuge, sino de ser el causante directo de la pérdida de la persona con la que se desarrollaba un proyecto de vida en común y con la que se mantenía una especial relación de afectividad. Por ello, entiendo que habrá que considerar indigno e incapaz de suceder a la persona que sea condenada por haber atentado contra la vida de la pareja de hecho del testador.

${ }^{119}$ Jóse Pérez de Vargas está a favor de que se realice una interpretación restrictiva en esta materia, por idénticos motivos por los que el divorciado o el que se encuentra con que su matrimonio está anulado, no pueden tampoco ser considerado cónyuges, véase José Pérez de Vargas Muñoz, La indignidad sucesoria en el Código civil español, Madrid, Mc Graw Hill, 1997, p. 76. 
- En las disposiciones relativas a los límites legales a la libertad de testar: la preterición y la desheredación

del conviviente supérstite

Respecto a los límites legales a la libertad de testar que los miembros de la pareja de hecho pueden tener a la hora de otorgar testamento, para no resultar reiterativa, voy a partir de las conclusiones extraídas del anterior epígrafe sobre el reconocimiento de derechos sucesorios legitimarios al conviviente supérstite. Como expuse, considero que se dan todos los requisitos favorables a la aplicación analógica de los derechos legitimarios del cónyuge viudo al compañero sobreviviente supérstite. Por lo tanto, en el ámbito del Derecho Civil común, entiendo que si el testador no realiza ninguna disposición a favor de su pareja de hecho, ésta podrá considerarse preterida (art. 814 del $C C$ ) y no podrá ver perjudicado su derecho al usufructo viudal legitimario por las disposiciones testamentarias. A su vez, el cohabitante testador puede llevar a cabo todas las disposiciones testamentarias a favor de su pareja de hecho con total libertad, si bien, tendrá las mismas limitaciones que cualquier otro ciudadano teniendo en cuenta sus restantes circunstancias familiares (v.gr. existencia de descendientes, ascendientes...).

En mi opinión, es posible hablar de la preterición de la pareja de hecho en el testamento, puesto que el conviviente supérstite, por analogía, afirmo que es un heredero forzoso ${ }^{120}$. El hecho de que éste sobreviviente no sea nombrado en el testamento o que no se realice ninguna disposición en su favor no anula la institución de heredero, ni las disposiciones de carácter patrimonial, pero puede dar lugar a la acción de reducción o complemento de los legados, las mejoras y demás disposiciones testamentarias, respecto de lo que dicha omisión lesione su derecho a la legítima (art. 814 del $C C)^{121}$.

De igual manera, creo que es posible hablar de desheredación del conviviente supérstite. Por esta vía, se le podría privar mediante la expresión

${ }^{120} \mathrm{Al}$ igual que José M. Miquel González, considero que: "la preterición no es un problema de legítima, porque no siempre se otorga la cuota de legítima, sino la cuota intestada a través de la nulidad de la institución de heredero (claramente en el caso de la preterición no intencional) y porque desde el punto de vista de la legítima es indiferente la voluntad del testador. Lo que está relacionado con la falta de declaración de voluntad testamentaria es la sucesión intestada, no la legítima. [...]", véase José María MiQuel GonzÁlez, "Notas sobre 'la voluntad del testador", en Revista Jurídica de la Universidad Autónoma de Madrid, Homenaje a D. Luis Diez-Picazo, No 6, Madrid, Dykinson, 2002, pp. 159-176.

${ }^{121}$ Véase SAP Alicante de 17 de mayo de 2001 [AC, 2001, 1177]. En esta sentencia, tras una convivencia de hecho de más de cincuenta años de duración, en el testamento el causante no realiza ninguna disposición a favor de la conviviente supérstite. La exclusión del testamento de la conviviente se considera que es perfectamente válida, pero se califica por el Tribunal de "incomprensible" (fundamento jurídico $2^{\circ}$ ). 
de justa causa en el testamento de los derechos legitimarios que, como heredero forzoso, creo que le corresponden. Si sostengo que los convivientes, por analogía, son herederos forzosos, es necesario que exista una justa causa para no reconocerles estos derechos sucesorios (art. $851 \mathrm{del} C C$ ). De dichas justas causas para desheredar a la pareja de hecho, además de las generales contempladas en los artículos 852,853 y 854 del $C C$, considero aplicables, por analogía, todas las causas específicas de desheredación del cónyuge contempladas en el artículo 855 del $C C$. No obstante, en relación con estas últimas causas, lo más común es que cuando se den las circunstancias desencadenantes de las mismas, la convivencia more uxorio se rompa y los miembros de la pareja de hecho pierdan respectivamente sus derechos sucesorios; pero lo harán por la ruptura de su relación y no por la concurrencia de una justa causa de desheredación ${ }^{122}$. Si la convivencia continúa a pesar de la concurrencia de circunstancias que justifican la exclusión, en cada caso concreto habrá que precisar si el testador, a pesar de conocerlas, las tiene en cuenta para desheredar y privar a su pareja del derecho a la legítima, pero no para romper la convivencia; o si, por el contrario, es necesario entender que existe un perdón o reconciliación entre los convivientes, puesto que continúan conviviendo, en cuyo caso no constituirían una justa causa de desheredación ${ }^{123}$.

\section{- Las disposiciones relativas a la cautela socini}

También conviene destacar que, en la actualidad, son numerosos los testadores que disponen el usufructo universal de todos sus bienes en favor de su cónyuge a través de la denominada cautela socini ${ }^{124}$. El empleo de esta cautela testamentaria es admitido por la mayoría de la doctrina y de la jurisprudencia ${ }^{125}$, entendiéndose que con esta disposición no se vulnera

${ }^{122}$ BRANCós NúÑEz (n. 95), p. 1.027.

${ }^{123}$ Véase Francisco Jordano Fraga, Indignidad sucesoria y desheredación (Algunos aspectos conflictivos de su recíproca interrelación), Granada, Comares, 2004, pp. 172-174 y Aurelia María Romero Coloma, La desheredación. De descendientes, padres y ascendientes, y del cónyuge. Estudio jurisprudencial y doctrinal de sus causas, Barcelona, Bosch, 2005, pp. 129-160.

${ }^{124} \mathrm{La}$ cautela socini se define como la cautela que: "tiene lugar cuando el testador deja al legitimario una parte de la herencia de mayor valor que lo que a éste le corresponde por legítima, gravando lo así dejado con usufructos, pensiones, fideicomisos, condiciones u otra clase de gravámenes o limitaciones, pero con la prevención de que si el legitimario no aceptara íntegramente dichos gravámenes o limitaciones, perderá lo que se le ha dejado por encima del importe de la legítima, debiendo entonces contentarse en adquirir lo que por vía de la legítima estricta le corresponde"; véase Ramón María Roca SASTRE, Estudios de Derecho Privado, Madrid, Revista de Derecho Privado, 1948, vol. II: Sucesiones, p. 174.

${ }^{125}$ Véase Ana L., Cabezudo Arenas, "Reflexiones sobre la cautela socini”, en Antonio Cabanillas Sánchez (coord.), Estudios Jurídicos en Homenaje a Luis Díez-Picazo, Madrid, Thomson-Civitas, 2003, tomo IV, pp. 5.141-5.143 y Diversas formas de canalización de la Cautela 
el principio de la intangibilidad cuantitativa de la legítima (art. $813.2^{\circ}$ del $C C$ ), por lo que cobra un protagonismo mayor la voluntad del testador como ley de la sucesión. La diferencia fundamental con la previsión del artículo $820.3^{\circ}$ del $C C$ es la posición que ocupan los legitimarios, puesto que en el contexto del artículo $820.3^{\circ} \mathrm{CC}$, aquéllos que no deseen soportar el gravamen pueden entregar al viudo el tercio de libre disposición, accediendo a la legítima completa; mientras que, mediante la cautela socini, la alternativa que se da por el testador a los legitimarios es menor, pues si no admiten el gravamen establecido, sólo tendrán derecho a percibir lo que por legítima estricta les corresponda.

Por lo tanto, en Derecho Común, en el caso de la pareja sobeviviente existe realmente diferencia entre el establecimiento de la opción testamentaria de la cautela socini y la aplicación de lo dispuesto en el artículo 820.3 del $C C$, porque si consideramos que el conviviente supérstite es legitimario, la opción del resto de los herederos con los que concurra es sustancialmente distinta en uno y otro caso y, por ello, el establecimiento de este tipo de cautelas por el testador a favor de su pareja en el testamento puede configurarse como un medio idóneo para protegerlo o para organizar el patrimonio familiar ${ }^{126}$.

- En las disposiciones relativas a la atribución de la facultad de mejorar

Finalmente, dentro de esta mención a las disposiciones de la sucesión testada, sin duda he de destacar la facultad de mejorar se contempla en el artículo 831 del $C C$. Este artículo (modificado por la Ley 41/2003, de 18 de noviembre, de protección patrimonial de las personas con discapacidad),

Socini, Valencia, Tirant, Monografías No 225, 2002, pp. 191-214 y Luis F. RAGEL SÁnchez, La cautela gualdense o Socini y el artículo $820.3^{\circ}$ del Código civil, Madrid, Dykinson, 2004, pp. 147-149. Entre la jurisprudencia podemos destacar las últimas sentencias del Tribunal Supremo sobre esta materia, por ejemplo, las SSTS de 3 de diciembre de 2001 [RJ, 2001, 9925] y 10 de julio de 2003 [RJ, 2003, 4628], que expresamente reconocen la validez de la cautela socini como cláusula testamentaria que no comporta un gravamen sobre la legítima, sino una opción para los legitimarios.

${ }^{126}$ Sin embargo, si se considera que la analogía con los derechos del cónyuge viudo no es posible, a pesar de que se establezca esta opción de la cautela socini a los legitimarios, éstos tendrán que optar entre adquirir toda la legítima -ya que el conviviente no tendría reconocido el usufructo viudal- o la nuda propiedad de toda la herencia, incluido el tercio de libre disposición. Como opción es perfectamente válida, pero, salvo que el conviviente supérstite sea de una avanzada edad y exista una buena intención de los legitimarios por el respeto a la voluntad del causante, en el resto de supuestos de hecho, difícilmente éstos aceptarán esta opción testamentaria y, con ello, el testador no conseguirá el objetivo esencial que pretende al imponer esta cautela, que es favorecer y asegurar la situación patrimonial de su pareja hasta su fallecimiento. 
permite delegar la facultad de mejorar a los hijos y descendientes comunes tanto a favor del cónyuge como a favor de la persona con la que, sin haber contraído matrimonio, se tengan hijos comunes. Nos encontramos ante una modificación del Código Civil español por la que se está reconociendo la posibilidad de otorgar al conviviente supérstite un efecto jurídico mortis causa, como es la delegación de la facultad de mejorar a los hijos. El legislador, mediante esta reforma, parece responder a ciertas opiniones doctrinales, manifestadas con ocasión de la reforma del Código Civil de 1981, que destacaron que el fundamento de esta institución se encuentra "más que en la affectio maritalis, en la confianza que se deriva de que el comisario sea padre o madre de los llamados a heredar" 127 .

Esta nueva redacción del artículo 831 del $C C$ permite afirmar que la disposición testamentaria por la cual el conviviente testador delegue la facultad de mejorar a su conviviente supérstite, para que éste pueda realizar a favor de los hijos o descendientes comunes las mejoras que estime oportuno, es una disposición testamentaria válida. Esta reforma tiene una especial relevancia, porque constituye la primera disposición que en el Código Civil español reconoce expresamente una facultad al conviviente supérstite en el ámbito del Derecho de sucesiones.

\section{6 d) La excepcionalidad de los preceptos sucesorios}

Retomando el estudio de los requisitos de la analogía, una vez que se acredita la existencia de la laguna legal, la identidad de razón entre el supuesto de hecho regulado y el no regulado y la identidad de la ratio legis en cada una de las disposiciones jurídicas, el último requisito es que no exista una disposición legal que impida acudir al argumento analógico. En nuestro caso, la principal objeción que puede oponerse es considerar que los derechos sucesorios mencionados son excepcionales, porque derogan el principio general que rige en el Derecho de Sucesiones, es decir, la libertad de testar. $\mathrm{O}$ sea, que se considere que las normas sucesorias son excepcionales y que, en virtud del artículo 4.2 del $C C$, no procede la analogía ${ }^{128}$.

A mi juicio, ni los derechos sucesorios ex lege ni las disposiciones testamentarias mencionadas son normas excepcionales, sino sucesorias

${ }^{127}$ Aurelio DíEz Gómez, "El nuevo artículo 831 del Código civil”, en Revista de Derecho Notarial, No 117-118, Madrid, julio-diciembre 1982, pp. 414-415; Francisco Millán SALAs, "La delegación de la facultad de mejorar del artículo 831 del Código civil”, en Revista General de Legislación y Jurisprudencia, No 3, Madrid, julio-agosto, 2006, pp. 403-434 y José María MiQUeL González, "Comentario al artículo 831", en Manuel Amorós Guardiola, Comentarios a las Reformas de Derecho de Familia, Madrid, Tecnos, 1984, vol. II, pp. 1.311-1.318.

${ }^{128}$ Gullón Ballesteros (n. 90), p. 30 y José María Pena López, "Comentario al artículo 4 CC”, en Rodrigo Bercovitz Rodríguez-Cano, Natalia Alvárez Lata, Comentarios al Código Civil, Navarra, Aranzadi, 2001, p. 36. 
que sirven para garantizar la continuidad de las relaciones jurídico-patrimoniales tras el fallecimiento, pero atendiendo al valor constitucional de protección económica de la familia (art. 39 de la CE). Existe una relación causa-efecto entre la consideración del modelo familiar imperante en un determinado momento y la respuesta jurídica que se le otorga a este modelo en la sucesión mortis causa. Esto es, en el Derecho de Sucesiones, junto a la libertad de testar, coexisten y se protegen otros valores constitucionales, cuyo respeto permite cumplir la función social que la herencia tiene atribuida constitucionalmente (art. 33.2 de la $\mathrm{CE}$ ), delimitando su propio contenido; función social que no se limita al ámbito público, es decir, a la participación de la colectividad en la herencia (v.gr. impuesto de sucesiones y donaciones), sino que implica garantizar otras instituciones en el ámbito público-privado, como, por ejemplo, la familia (art. 39 de la CE). Así, en mi opinión, la existencia de los derechos legitimarios del cónyuge viudo supone un reconocimiento de su derecho a heredar como miembro del modelo familiar protegido y constituye un medio para asegurar la protección económica de la familia ${ }^{129}$.

El principio general en Derecho de Sucesiones es el derecho a la herencia del artículo 33 de la $\mathrm{CE}^{130}$ y no, sólo, la libertad de testar ${ }^{131}$. Por ello, mantengo que tanto los derechos abintestato, los derechos legitimarios, la reserva viudal, así como las mencionadas disposiciones testamentarias, no son normas excepcionales, sino reglas fundamentales de Derecho de

${ }^{129}$ Según Teodora Torres García, "la garantía institucional de la herencia del artículo 33.1 abarca a la familia ya que el derecho sucesorio ha sido históricamente un derecho de tradición familiar" y trae a colación la Sentencia del Tribunal Constitucional Alemán (BGH 1644/00 de 19 de abril de 2005), donde se afirma: "al tener la familia garantía constitucional su protección no resulta cuestionada de suerte que la acción de privación de la legítima no sólo se extingue por no ejercitar el derecho sino que ha de basarse en una de las causas tipificadas". Además, la sentencia lleva a cabo una interpretación integradora de los § 6 y 14 GG (relativos a la protección de la familia y al reconocimiento del derecho de propiedad), vid. Teodora F. Torres García, "Legítima, legitimarios y libertad de testar (síntesis de un sistema)", en Derecho de sucesiones. Presente y futuro, Murcia, Universidad de Murcia, Servicio de Publicaciones, 2006, pp. 220-221.

${ }^{130}$ Sobre la consideración del derecho a la propiedad y la herencia como garantía institucional en la Constitución, véase Ángel María LóPEz y LóPEz, "La garantía institucional de la herencia”, en Derecho Privado y Constitución, No 3, Madrid, mayo-agosto 1994, pp. 43-62 y Aurelia María Romero Coloma, "El derecho a la herencia en el Ordenamiento jurídico español. Especial referencia a la función social de este derecho", en Revista Crítica de Derecho Inmobiliario, $\mathrm{N}^{\mathrm{O}}$ 638, Madrid, enero-febrero 1997, p. 156.

${ }^{131}$ Luis Díez-Picazo y Antonio Gullón afirman: “[...] la sucesión por causa de muerte responde a una necesidad social [...] supuesta la necesidad del fenómeno hereditario, en su organización jurídica juegan ya criterios de política jurídica, que será muy distinta según la relevancia que se dé a factores como el interés de la familia, la perpetuación de la propiedad individual o los intereses sociales", (n. 105), pp. 297-298. 
Sucesiones destinadas a garantizar valores constitucionales de protección social, económica y jurídica de la familia en el desarrollo de la función social del derecho a heredar (art. 33. 2 de la CE). Los citados derechos no configuran una excepción, sino que constituyen una regla institucional del Derecho de Sucesiones.

\section{REFLEXIÓN FINAL}

En España, en el ámbito de aplicación del Derecho Civil común, considero admisible el reconocimiento por analogía legis al conviviente supérstite de los derechos sucesorios ex lege del cónyuge viudo, así como las citadas disposiciones de la sucesión testada. Dicha argumentación implica cierta inseguridad jurídica, pero ésta no se debe al empleo del argumento jurídico por analogía (si éste está debidamente justificado), sino a la ausencia de una regulación estatal sobre esta materia. A mi juicio, el principio de igualdad no puede verse vulnerado con el fin de alcanzar una mayor seguridad jurídica, cuando de lo que se trata es de conseguir un objetivo constitucional.

De hecho, reitero que este reconocimiento no debilita la institución familiar, ni lesiona la autonomía y la libertad de los sujetos, sino que permite equiparar en sus efectos dos situaciones entre las que existe una identidad de razón suficiente. En España, en la actualidad, la pareja de hecho es una familia constitucionalmente protegida (art. 39 de la CE) y la vigencia de la convivencia more uxorio en el momento del fallecimiento, tras las reformas legislativas de 2005, es la principal causa de atribución de los derechos sucesorios del cónyuge viudo. Por todo ello, considero que está plenamente justificada y es de justicia, la aplicación de los mencionados derechos sucesorios del cónyuge viudo al conviviente supérstite a través de la analogía legis.

\section{BibliografíA}

Alberdi, Inés, La nueva familia española, Madrid, Taurus, 1999.

Álvarez Lata, Natalia, "Las parejas de hecho: perspectiva jurisprudencial", en Derecho Privado y Constitución, No 12, Madrid, 1998.

Amunátegui Rodríguez, Cristina de, Uniones de hecho. Una nueva visión después de la publicación de las Leyes sobre parejas estables, Valencia, Tirant, Monografías $\mathrm{N}^{\circ}$ 221, 2002.

Atienza Rodríguez, Manuel, Sobre la analogía en el Derecho. Ensayo de análisis de un razonamiento jurídico, Madrid, Civitas, 1986. 
Bercovitz Rodríguez-Cano, Rodrigo, "La pareja de hecho", en Aranzadi Civil, vol. I, Navarra, 1993.

Bermejo Pumar, María Mercedes, "Atribuciones legales: la legítima", en Juan Francisco Delgado De Miguel, Instituciones de Derecho Privado, tomo v, vol. III, Madrid, Thomson-Civitas, 2005.

Blanco Pérez-Rubio, Lourdes, Parejas no casadas y pensión de viudedad, Madrid, Editorial Trivium, 1992.

BRancós NúÑEZ, Enrique, "Derechos sucesorios de las uniones estables de pareja", en Juan Francisco Delgado de Miguel, Instituciones de Derecho Privado, tomo v, vol. III, Madrid, Thomson-Civitas, 2005.

Brancós NúÑEz, Enrique, "Atribuciones legales (legítimas, los derechos del cónyuge viudo y de las parejas, reservas). Derechos sucesorios de las uniones estables de pareja”, en Juan Francisco Delgado De Miguel, Instituciones de Derecho Privado, tomo v, vol. III, Madrid, Thomson-Civitas, 2005, pp. 945-1.028.

Bustos Lago, José M., "Comentario al artículo 968 CC", en Rodrigo Bercovitz Rodríguez-Cano, Natalia Alvárez Lata, Comentarios al Código Civil, Navarra, Aranzadi, 2001.

Cabezudo Arenas, Ana L., "Reflexiones sobre la cautela socini", en Antonio Cabanillas Sánchez (coord.) Estudios Jurídicos en Homenaje a Luis Díez-Picazo, Madrid, Thomson-Civitas, 2003, tomo IV.

Cabezudo Arenas, Ana L., Diversas formas de canalización de la Cautela Socini, Valencia, Tirant, Monografías No 225, 2002.

Campo Urbano, Salustiano del, La nueva familia española, Madrid, Eudema, 1991.

Cano Tello, Celestino, "El artículo 834 del Código civil desde la perspectiva de los derechos históricos y de los principios del Derecho de familia español", en Centenario del Código civil, Madrid, Centro de Estudios Ramón Areces, 1990, vol. I.

Cantero NúÑEz, Federico J., "Reflexiones en torno a la pretendida regulación de las uniones de hecho", en Revista de Derecho Privado, año 79, No 3, Madrid, marzo 1995.

Cantero NúÑez, Federico, "Uniones de hecho", en Juan Francisco Delgado de Miguel, Instituciones de Derecho privado. Familia, tomo IV, vol. I, Madrid, Civitas, 2001.

Carbonnier, Jean, Derecho flexible. Para una sociología no rigurosa del Derecho, Madrid, Tecnos, 1974.

Carbonnier, Jean, Flexible Droit. Pour une sociologie du Droit sans rigueur, $10^{\mathrm{a}}$ ed., Paris, L.G.D.J., 2001.

Carrasco Perera, Ángel, "Comentario al artículo 16 LAU”, en Rodrigo Bercovitz Rodríguez-Cano, Comentarios a la Ley de Arrendamientos Urbanos, Navarra, Aranzadi, 2002.

Cervera Soto, Teresa, "Breves reflexiones sobre la regulación jurídica de las uniones no matrimoniales", en Revista de Derecho Privado, año 84, No 3, Madrid, 2000. 
Cervilla Garzón, María Dolores, "Pensión compensatoria y uniones de hecho en la jurisprudencia del Tribunal Supremo", en Revista de Derecho Patrimonial, $\mathrm{N}^{\mathrm{O}} 10$, Navarra, 2003.

CRespo Allué, Fernando, "Comentario al nuevo artículo 834 del Código civil”, en Vicente GuILARTE GutiÉRrez y otros, Comentarios a la reforma de la separación y el divorcio: Ley 15/2005, de 8 de julio, Valladolid, Lex Nova, 2005.

Crespo Allué, Fernando, “Comentario al nuevo artículo 945 CC”, en Vicente Guilarte Gutiérrez y otros, Comentarios a la reforma de la separación y el divorcio: Ley 15/2005, de 8 de julio, Valladolid, Lex Nova, 2005.

Crespo Mora, María Carmen, "Ruptura de la unión: aplicación analógica de las normas sobre crisis matrimonial. Comentario a la STS de 27 de marzo de 2001", en Revista de Derecho Patrimonial, Nº 9, Navarra, Aranzadi, 2002.

CRuz Villalón, Pedro, "Formación y evolución de los Derechos fundamentales", en Revista Española de Derecho Constitucional, año 9, № 25, Madrid, enero-abril 1989.

Chinchilla Marín, Carmen, "La familia en la jurisprudencia del Tribunal Constitucional”, en Aranzadi Civil, vol. I, Navarra, 1995.

Delgado, Margarita A., "Cambios recientes en el proceso de formación de la familia”, en Revista Española de Investigaciones Sociológicas, № 64, Madrid, 1993.

60 Derecho Civil, tomo LIx, fascículo III, Madrid, julio-septiembre 2006.

Díez Gómez, Aurelio, "El nuevo artículo 831 del Código civil”, en Revista de Derecho Notarial, No 117-118, Madrid, julio-diciembre 1982.

DíEz-PicAzo, Luis, Experiencias jurídicas y teoría del Derecho, Barcelona, Ariel, 1973.

Díez-Picazo, Luis María, Sistema de Derechos Fundamentales, Madrid, ThomsonCivitas, 2003.

Díez-Picazo y Ponce de León, Luis, Familia y Derecho, Madrid, Civitas, 1984.

Díez-Picazo y Ponce de León, Luis, "De quelque paradoxes dans la protection juridique des couples de fait en Droit espagnol", in Études ofertes à Jacqueline Rubellin-Devichi. Des concubinages: droit interne, droit internacional et droit comparé, Paris, Litec-Editions du JurisClasseur, 2002.

Díez-Picazo y Ponce de León, Luis y Gullón Ballesteros, Antonio, Sistema de Derecho Civil, Madrid, Thomson-Civitas, 2006.

Engels, Friedrich, El origen de la familia, Madrid, Albor, 1998.

EsPada Mallorquín, Susana, "Enriquecimiento injusto y protección jurídica del conviviente supérstite. Comentario a la STS de 17 de junio de 2003”, en Revista de Derecho Patrimonial, No 12, Navarra, Aranzadi, 2004.

Espada Mallorouín, Susana, Los derechos sucesorios de la pareja de hecho, Navarra, Thomson-Civitas, 2007.

Espejo Lerdo de TejadA, Manuel, La legítima en la sucesión intestada en el Código civil, Madrid, Marcial Pons, 1996. 
Espert SANZ, Vicente, “Comentario a la STS de 18 de mayo de 1992", en Revista General de Derecho, No 753-574, Madrid, julio-agosto 1992.

Espín CÁnOVAS, Diego, "Familia no matrimonial", en José Luis Lacruz Berdejo (presidente), Ponencias del Congreso Hispanoamericano de Derecho de Familia, Cáceres, Plasencia y Trujillo, s.e., No 36, 1987.

Estelles Peralta, Patricia, "Parejas de hecho y subrogación en el arrendamiento", en Revista General de Derecho, N 637-638, Madrid, octubre-noviembre 1997.

Estrada Alonso, Eduardo, La unión extramatrimonial en el Derecho civil español, $2^{\mathrm{a}}$ ed. Madrid, Civitas, 1991.

Falcón y Tella, María José, El argumento analógico en el Derecho, Madrid, Civitas, 1991.

Ferreres Comella, Víctor, "El principio de igualdad y el "derecho a no casarse" (A propósito de la STC 222/1992)”, en Revista Española de Derecho Constitucional, año 42, No 14 , Madrid, septiembre 1994.

FlaQUer, Luis, “¿Hogares sin familia o familias sin hogar?”, en Papers: Revista de Sociología, No 36, erevistas.csic.es, 1991.

Flaquer, Luis, El destino de la familia, Barcelona, Ariel, 1998.

FLAQUer, Luis, "Familia y políticas públicas", en Anuario de la Facultad de Derecho de la Universidad Autónoma de Madrid, N 10, Madrid, 2006.

FLor Fernández, María Luisa de la, Régimen jurídico de la pensión de viudedad, Sevilla, Mergablum. Edición y Comunicación, S.L., 2002.

Fuentes Lojo, Juan V., Novísima Suma de Arrendamientos Urbanos, adaptada a la nueva LEC de 7 de enero de 2000 en lo procesal y al día en el ámbito doctrinal y jurisprudencial en lo sustantivo, Barcelona, Bosch, 2001, tomo I.

Gálvez Montes, F. Javier, “Comentario al artículo 32 CE”, en Fernando Garrido Falla, Comentarios a la Constitución, Madrid, Civitas, 1980.

Gallego Domínguez, Ignacio, La pareja no casada y sus efectos patrimoniales, Madrid, Centro de Estudios Registrales, 1995.

García Cantero, Gabriel, "Sucesión intestada a favor de convivientes (Una resolución sorprendente de la Audiencia Provincial de Alicante)", en Revista Jurídica del Notariado, No 43, Madrid, julio-septiembre 2002.

García Goyena, Florencio, Concordancias, motivos y comentarios del Código civil español, apéndice número 10, Madrid, Imprenta de la Sociedad Tipográfico-Editorial, 1852, vols. I-II, y Barcelona, Editorial Base, 1973.

García-Posada Gómez, Elda, "El concepto de convivencia no matrimonial en Derecho español”, en Anuario de Derecho Civil, tomo LVI, fascículo III, Madrid, julio-septiembre 2003.

García-Ripoll Montijano, Martín, "Equiparación entre parejas de hecho heterosexuales al matrimonio, y equiparación de parejas heterosexuales de hecho a las homosexuales”, en Aranzadi Social, vol. III, Navarra, 1998. 
García Rubio, María Paz, "Pareja de hecho y lealtad constitucional", en Teodora Felipa Torres García (coord.), Estudios de Derecho civil: homenaje al Profesor Francisco Javier Serrano García, Valladolid, Unoiversidad de Valladolid, 2004.

García Rubio, María Paz, "La modificación del Código civil en materia de derecho a contraer matrimonio", en La Ley, $\mathrm{N}^{\circ}$ 6359, Madrid, 15 de noviembre de 2005, vol. 5, ref. D-264.

García Rubio, María Paz, "Las uniones de hecho en España. Una visión jurídica”, en Anuario de la Facultad de Derecho de la Universidad Autónoma de Madrid, No 10, Madrid, 2006.

Garrido Melero, Martín, "El régimen jurídicos de las parejas de hecho" en VV.AA., El nuevo derecho de familia: modificaciones legislativas y tendencias doctrinales, Madrid, Thomson-Civitas, 2006.

Gavidia Sánchez, Julio V., La unión libre (El marco constitucional y la situación del conviviente supérstite), Valencia, Tirant lo blanch, 1995.

Gavidia Sánchez, Julio V., "La libertad de elección entre el matrimonio y la unión libre", en Derecho Privado y Constitución, No 12, Madrid, Centro de Estudios Políticos y Constitucionales, 1998.

Gavidia SÁnchez, Julio V., "¿Es la unión libre una situación análoga al matrimonio?”, en Revista Jurídica del Notariado, $\mathrm{N}^{\mathrm{O}}$ 32, Madrid, octubre-diciembre de 1999.

Gavidia SÁnchez, Julio V., "Analogía entre el matrimonio y la unión de hecho en la jurisprudencia del Tribunal Supremo y el principio de libre ruptura de la unión no matrimonial", en Aranzadi Civil, N ${ }^{\circ} 1$ Navarra, 2002.

Gavidia Sánchez, Julio V., "La unión libre: familia, no matrimonio", La Ley, $\mathrm{N}^{\circ}$ 6038, Madrid, 1 de junio de 2004, D- 131.

Gitrama GonzÁlez, Manuel, "Notas sobre la problemática jurídica de la pareja no casada”, en VV.AA. Libro Homenaje al Profesor José Beltrán de Heredia y Castaño, Salamanca, Ediciones de la Universidad de Salamanca, Publicaciones del departamento de Derecho Civil, 1984.

Gomá Lanzón, Ignacio, "Los derechos sucesorios del cónyuge viudo", en Juan Francisco Delgado de Miguel, Instituciones de Derecho Privado, tomo v, vol. III, Madrid, Thomson-Civitas, 2005.

Gómez Sánchez, Yolanda, Familia y Matrimonio en la Constitución de 1978, Madrid, Monografías del Congreso de los Diputados, 1990.

Gómez SÁnchez, Yolanda, "Matrimonio y Familia: artículos 32 y 39 de la Constitución", en Revista de Derecho Político, No 36, Madrid, 1992.

González Bou, Emilio, "Reservas hereditarias", en Juan Francisco Delgado de Miguel, Instituciones de Derecho Privado, tomo v, vol. III, Madrid, ThomsonCivitas, 2005.

GonzÁlez Porras, José M., "La familia sin matrimonio (Notas a propósito de dos Proyectos de ley italianos sobre la familia de hecho)", Revista Actualidad Civil, $\mathrm{N}^{\mathrm{o}}$ 31, Madrid, 1990. 
Gullón Ballesteros, Antonio, "Comentario al artículo 4 CC", en Comentarios al Código civil, Madrid, Ministerio de Justicia, 1993.

Jiménez Blanco, Antonio, "Garantías institucionales y derechos fundamentales en la Constitución”, en Sebastián Martín-Retortillo Baquer (coord.), Estudios sobre la Constitución española: Homenaje al profesor Eduardo García de Enterría, Madrid, Civitas, 1991, vol. 2.

Jordano Fraga, Francisco, Indignidad sucesoria y desheredación (Algunos aspectos conflictivos de su recíproca interrelación), Granada, Comares, 2004.

Larenz, Karl, Metodología de la Ciencia del Derecho, Barcelona, Ariel Derecho, 1994.

Levi-Strauss, Claude, Las estructuras elementales del parentesco, Barcelona, Paidós, 1969.

López Cumbre, Lourdes, "Comentario al artículo 174 LGSS", en Enrique de la Villa Gil, Luis, Ley General de la Seguridad Social, Comentarios, Jurisprudencia, Concordancias y Doctrina, Madrid, Colex. Editorial Constitución y Leyes, S.A. 2004.

López y López, Ángel María, "La garantía institucional de la herencia", Derecho Privado y Constitución, No 3, Madrid, mayo-agosto 1994.

López Peláez, Patricia, "Registros administrativos de parejas de hecho: incidencia en ellos de la nueva regulación del matrimonio", en Carlos LASARTE Álvarez, Fátima Yáñez Vivero, Araceli Donado Vara, María Fernanda Moretón SANZ (coords.), Familia, matrimonio y divorcio en los albores del siglo XXI, Madrid, UNED, IDADFE y El Derecho, 2006.

Llebaría SAmper, Sergio, Hacia la familia no matrimonial, Barcelona, Ceders, 1997.

Martínez de Aguirre, Carlos, "Las uniones de hecho: Derecho aplicable (I)", en Revista Actualidad Civil, No 4, Madrid, 1999.

MARTín Pérez, José A, “Convivencia y herencia. Derechos sucesorios en las uniones de hecho”, en Ramón Herrera Campos (coord.) Homenaje al profesor Bernardo Moreno Quesada, Almería, Universidad de Almería, Servicio de Publicaciones, 2000, vol. II.

Maside Miranda, José E., Legítima del cónyuge supérstite, Madrid, Centro de Estudios Hipotecarios, 1989.

Meil Landwerlin, Gerardo, La postmodernización de la familia española, Madrid, Acento, 1999.

Meil Landwerlin, Gerardo, Las uniones de hecho en España, Madrid, Centro de Investigaciones Sociológicas, Monografía No 201, 2003.

Meil Landwerlin, Gerardo, "Actitudes y uso social de las uniones de hecho en España", en Anuario de la Facultad de Derecho de la Universidad Autónoma de Madrid, $\mathrm{N}^{\mathrm{O}}$ 10, Madrid, 2006.

Mesa Marrero, Carolina, Las uniones de hecho: análisis de las relaciones económicas y sus efectos, $3^{\mathrm{a}} \mathrm{ed}$., Navarra, Thomson-Aranzadi, 2006. 
Michel, Andrée, Sociología de la familia y del matrimonio, Barcelona, Península, 1974.

Millán Salas, Francisco, "La delegación de la facultad de mejorar del artículo 831 del Código civil", en Revista General de Legislación y Jurisprudencia, $\mathrm{N}^{\circ} 3$, Madrid, julio-agosto, 2006.

Miquel González, José María, "Comentario a los artículos 761-814 CC", en Manuel Amorós Guardiola, Comentarios a las Reformas de Derecho de Familia, Madrid, Tecnos, 1984, vol. II.

Miquel González, José María, "Comentario al artículo 831", en Manuel Amorós Guardiola, Comentarios a las Reformas de Derecho de Familia, Madrid, Tecnos, 1984, vol. II.

Miquel GonzÁlez, José María, “Notas sobre 'la voluntad del testador”, en Revista Jurídica de la Universidad Autónoma de Madrid, Homenaje a D. Luis Díez-Picazo, No 6, Madrid, Dykinson, 2002.

Moreno Verdejo, Jaime, "Algunas reflexiones sobre los registros municipales de uniones civiles no matrimoniales", en Revista General de Derecho, No 603, Madrid, diciembre 1994.

Pantaleón Prieto, A. Fernando, “¿Derechos sucesorios abintestato del compañero o compañera en la Compilación de Derecho civil de Cataluña?”, en Bartolomé Clavero, La reforma de la Compilación: el sistema successori. Materials III Jornades de Dret Català a Tossa, mar, 26-29 de septiembre de 1984, Barcelona, Universitat de Barcelona, Càtedra de Dret Civil Català "Duran i Bas", 1984

Pantaleón Prieto, A. Fernando, “Compañero/compañera”, en Enciclopedia Jurídica Básica, Madrid, Civitas, 1995, vol. I.

Pantaleón Prieto, A. Fernando, "El régimen jurídico civil de las parejas de hecho", en José María Martinell y María Teresa Areces Piñol (eds.), Uniones de hecho: XIJornades Jurídiques Lleida, Universitat de Lleida, Facultat de Dret i Economia, Departament de Dret Privat, 1998.

Parejo Alfonso, Luciano, Garantía institucional y Administraciones locales, Madrid, Instituto de Estudios de la Administración Local, 1981.

Pena López, José María, "Comentario al artículo 4 CC", en Rodrigo Bercovitz Rodríguez-Cano, Natalia Alvárez Lata, Comentarios al Código Civil, Navarra, Aranzadi, 2001.

PÉReZ de VARgas Muñoz, José, La subrogación de la vivienda arrendada y las parejas de hecho (Estudio jurisprudencial y doctrinal), Madrid, Editorial Complutense, 1995.

Pérez de Vargas Muñóz, José, La indignidad sucesoria en el Código civil español, Madrid, Mc Graw Hill, 1997.

Pérez Escolar, Marta, "Derechos sucesorios del conviviente supérstite. A propósito de la Sentencia del Tribunal Supremo de 17 de junio de 2003", en Revista Actualidad Civil, vol. I, Madrid, 2004.

Prieto SAnchís, Luis, Sobre principios y normas. Problemas del razonamiento jurídico, Madrid, Centro de Estudios Constitucionales, 1992. 
Pulido Quecedo, Manuel, "El principio de protección al conviviente perjudicado por la situación de hecho: cun nuevo principio general del derecho?”, en Revista Actualidad Jurídica Aranzadi, No 586, Navarra, 6 de marzo de 2003.

Ragel Sánchez, Luis F., La cautela gualdense o Socini y el artículo $820.3^{\circ}$ del Código civil, Madrid, Dykinson, 2004.

Rallo Lombarte, Artemi, "Uniones conyugales de hecho y Constitución (la necesidad de clarificar la contradictoria jurisprudencia constitucional)", en Revista General de Derecho, No 606, Madrid, marzo, 1995.

Rebolledo Varela, Ángel Luis, Separación de bienes en el matrimonio (el régimen convencional de la separación de bienes), Madrid, Editorial Montecorvo, 1983.

Reina, Víctor y José María Martinell, Las uniones matrimoniales de hecho, Madrid, Marcial Pons, 1996.

Rivero Hernández, Francisco, “Comentario a la STS 29 de octubre de 1997”, en Cuadernos Civitas de Jurisprudencia Civil, No 46, Madrid, 1998.

Roca I TRÍAs, Encarna, "Principi d'igualtat: matrimini i parella de fet (Comentari de la STC 184/1990, de 15 novembre)", en Revista Jurídica de Cataluña, vol. 90, No 2, Barcelona, 1991.

Roca I Trías, Encarna, “Comentario al artículo 4 del Código civil”, en Comentarios al Código civil y Compilaciones forales, Madrid, Edersa, 1992.

Roca Sastre, Ramón María, Estudios de Derecho Privado, Madrid, Revista de Derecho Privado, 1948, vol. II: Sucesiones.

Roca i Trías, Encarna, Familia y cambio social. (De la "casa" a la persona), Madrid, Cuadernos Civitas, 1999.

Roca I TRÍAS, Encarna "Repensar la pareja de hecho", en Encarna RocA I TRIAS y otros, Estudio comparado de la regulación autonómica de las parejas de hecho: soluciones armonizadoras, manuales de formación continuada, $\mathrm{N}^{\mathrm{o}} 28$, Madrid, Consejo General del Poder Judicial, 2005.

Roca I Trías, Encarna, "Familia y Constitución", en Anuario de la Facultad de Derecho de la Universidad Autónoma de Madrid, N $^{\circ}$ 10, Madrid, 2006.

Rodríguez Guitian, Alma María, "Función de la responsabilidad civil en determinadas relaciones de convivencia: daños entre cónyuges y daños entre miembros de la pareja de hecho", en Revista de Derecho Patrimonial, No 10, Navarra, 2003.

Rodríguez Ruiz, Blanca, "Posición constitucional de las parejas de hecho", en Encarna Roca I TRIAS y otros, Estudio comparado de la regulación autonómica de las parejas de hecho: soluciones armonizadoras, manuales de formación continuada, No 28, Madrid, Consejo General del Poder Judicial, 2005.

Romero Coloma, Aurelia María, "El derecho a la herencia en el Ordenamiento jurídico español. Especial referencia a la función social de este derecho", en Revista Crítica de Derecho Inmobiliario, No 638, Madrid, enero-febrero 1997.

Romero Coloma, Aurelia María, La desheredación. De descendientes, padres y ascendientes, y del cónyuge. Estudio jurisprudencial y doctrinal de sus causas, Barcelona, Bosch, 2005. 
Romero Pareja, Agustín, "Los derechos sucesorios de las uniones familiares no matrimoniales", en Diario La Ley, año XxIv, N 5757, Madrid, 9 de abril de 2003.

SAlazAr Bort, Santiago, "Comentario a la STS de 17 de enero de 2003. De nuevo sobre parejas no casadas", en Revista Actualidad Jurídica, año XI, No 513, Navarra, Aranzadi, 2001.

SalazAr Bort, Santiago, "Comentario a la STS de 27 de marzo de 2001. Uniones de hecho y compensación del trabajo doméstico", en Revista ActualidadJurídica, año XI, N 513, Madrid, 20 de diciembre de 2001.

Salazar Bort, Santiago, "Pareja de hecho y pensión compensatoria (Comentario a la STS de 5 de julio de 2001)", Actualidad Civil, № 2, Madrid, 2002.

Salguero Salguero, Manuel, Argumentación jurídica por analogía, Madrid-Barcelona, Marcial Pons, 2002.

Salvador Coderch, Pau, Marc R. Lloveras i Ferrer y Carles Seuba i TorreblanCA, "Amor et caritas. La parella de fet en el Dret successori de Catalunya", en Àrea de Dret Civil (coord.). Setenes Jornades de Dret Català a Tossa. El nou Dret Successori de Catalunya, Barcelona, Universitat de Girona. PPU, 1994.

SÁnchez Ferro, Susana, "Analogía e imperio de la ley", en Anuario de Filosofía del Derecho, No $13-14$, Madrid 1996.

SÁnchez Martínez, María Olga, "Constitución y pareja de hecho. El matrimonio y la pluralidad de estructuras familiares", en Revista española de Derecho Constitucional, $\mathrm{N}^{\mathrm{O}}$ 58, Madrid, enero-abril 2000.

Segura Ortega, Manuel, "El problema de las lagunas en el Derecho", en Anuario de Filosofía del Derecho, tomo vi, Madrid, 1989.

Serrano Moreno, José L., "Una propuesta para la tutela jurídica de la familia sin matrimonio (I)", en Revista Actualidad Civil, No 29, Madrid, 1987.

Solozábal Echavarria, Juan J., "Garantías institucionales", en Aragón, Manuel (coord.), Temas básicos de Derecho Constitucional, Madrid, Civitas, 2001, tomo III: Tribunal constitucional y derechos fundamentales.

Talavera Fernández, Pedro A, Fundamentos para el reconocimiento jurídico de las uniones homosexuales. Propuesta de regulación en España, Madrid, Universidad Carlos III de Madrid, Dykinson, Cuadernos Bartolomé de las Casas, $\mathrm{N}^{\mathrm{o}} 10$, 1999.

Talavera Fernández, Pedro A, La unión de hecho y el derecho a no casarse, Granada, Comares, 2001.

Torrero Muñóz, Magda, "La jurisprudencia del Tribunal Supremo y del Tribunal Constitucional ante las uniones de hecho", en Revista General de Derecho, No 648, Madrid, septiembre 1998.

Torres EscÁmez, Salvador, "La sucesión mortis causa del conviviente more uxorio", en Ramón Herrera Campos (coord). Parejas de hecho: curso de Verano de la Universidad Complutense en Almería, Granada, Publicaciones de la Real Academia Granadina del Notariado, 1996. 
Torres García, Teodora F., "Legítima, legitimarios y libertad de testar (síntesis de un sistema)", en Derecho de sucesiones. Presente y futuro, Murcia, Universidad de Murcia, Servicio de Publicaciones, 2006.

Valpuesta Fernández, Rosario, “Comentario a la STS de 22 de julio de 1993”, en Cuadernos Civitas de Jurisprudencia Civil, No 33, Madrid, 1993.

Valpuesta Fernández, María del Rosario, "Matrimonio (D ${ }^{\circ}$ Civil)", en Enciclopedia Jurídica Básica, Madrid, Civitas, 1995, vol. III.

Valpuesta Fernández, María del Rosario, "Otras miradas sobre la familia. La familia y sus funciones”, en José Manuel González Porras y Fernando P. Méndez GonZÁLEZ (coords.) Libro homenaje al profesor Manuel Albaladejo García, Murcia, Secretariado de Publicaciones e Intercambio Científico de la Universidad de Murcia, 2004, vol. 2

Valpuesta Fernández, María del Rosario, "La encrucijada de la familia: entre la realidad social y el Derecho", en Juan Manuel ABRIL CAmpoy y María Eulalia Amat Llari (coords.), Homenaje al profesor Lluís Puig i Ferriol, Valencia, Tirant lo Blanch, 2006.

VAllet De Goytisolo, Juan B., "Panorama de las legítimas y de su diversa naturaleza", en Libro-Homenaje a Lorenzo Herrera Mendoza, Caracas, Universidad Central de Venezuela, 1970, tomo I.

Vallet de Goytisolo, Juan B., "Comentario al artículo 968 CC", en Comentarios al Código Civil, Madrid, Ministerio de Justicia, 1993, tomo I.

Vallet de Goytisolo, Juan B., "La analogía en el Derecho", en Anuario de Derecho Civil, No 48, vol. III, Madrid, 1995.

Vega Sala, Francisco, "Las uniones de hecho en la jurisprudencia del Tribunal Supremo", en Luis ZARRALUQUi y otros, Cuestiones derivadas de los pleitos de familia, Madrid, Dykinson, 1996.

Verda y Beamonte, José Ramón de, "Principio de libre desarrollo de la personalidad y ius connubii (a propósito del ATC 222/1994)", en MartinelL, José María y María Teresa ArEces PIÑOL (eds.), Uniones de hecho: XIJornadesJurídiques Lleida, Universitat de Lleida, Facultat de Dret i Economia, Departament de Dret Privat, 1998.

Vidal Gil, Ernesto y María Teresa MarTín Morón, "Jurisprudencia y cambios legislativos: la equiparación del cónyuge y el conviviente more uxorio en la reciente doctrina del Tribunal Constitucional", en Revista General de Derecho, No 586-587, Madrid, julio-agosto 1993.

Villagrasa Alcaide, Carlos, "Los registros municipales de uniones civiles", en José María Martinell y María Teresa Areces Piñol (eds.), Uniones de hecho: XI Jornades Jurídiques Lleida, Universitat de Lleida, Facultat de Dret i Economia, Departament de Dret Privat, 1998. 